\title{
Fluxes of particulate matter, carbonates, organic carbon and nitrogen in the northern Adriatic continental shelf: A synthesis overview
}

\author{
Michele Giani, ${ }^{1 *}$ Juan Carlos Miquel, ${ }^{2 \#}$ Amelia De Lazzari, ${ }^{3}$ Alfredo Boldrin ${ }^{3}$ \\ ${ }^{1}$ Istituto Nazionale di Oceanografia e di Geofisica Sperimentale (OGS), via A. Piccard 54, 34151 Trieste, Italy; ${ }^{2}$ Environment Laboratories, \\ International Atomic Energy Agency, Monaco; ${ }^{3}$ Istituto di Scienze Marine ISMAR-CNR Castello 2737/F, 30122 Venezia, Italy \\ \#Present address: Institute Bobby, Cap d'Ail, France \\ *Corresponding author: mgiani@inogs.it
}

\begin{abstract}
Time series of composition and fluxes of settling particles in the marine environment, obtained by sediment traps, contribute to define the main processes driving the dynamics of particulate matter and of the time/space variability of benthic-pelagic exchanges. With this aim, the composition and seasonal and annual fluxes of settling matter, obtained from different projects and from published papers, at 13 sites of the Northern Adriatic shelf were estimated. The mean yearly particulate fluxes varied from 2763 to $14447 \mathrm{~g} \mathrm{~m}^{-2} \mathrm{y}^{-1}$, from 66 to 236 $\mathrm{gC} \mathrm{m}^{-2} \mathrm{y}^{-1}$ for organic carbon (OC) flux, from 861 to $7525 \mathrm{~g} \mathrm{~m}^{-2} \mathrm{y}^{-1}$ for carbonates and from 12 to $42 \mathrm{gN} \mathrm{m}^{-2} \mathrm{y}^{-1}$ for nitrogen (N). The fluxes were characterized by high seasonal variations with marked increase in autumn or in winter with respect to spring or summer. The sink of particles occurs in relatively short episodes as about $50 \%$ of annual particle flux settles in less than 1-2 months in the western coastal area. This seasonality can be related to the riverine discharges, primary production and wind regimes of the basin. Utilizing the N/OC ratio as an index for discriminating the different origin of organic matter (i.e., resuspended/riverine and autochthonous), the primary marine carbon flux was estimated to range from 10 to $28 \%$ of the OC fluxes and accounted for $8-40 \%$ of the primary production, depending on the site. Then, due to the shallow waters of the basin and to the relevant riverine inputs, the total fluxes near the sea bottom were highly dependent on resuspension and advective transport processes. The important contribution of these last processes as source of organic matter is suggested also by the comparison between fluxes determined by sediment traps with mass accumulation rates (MAR) in sediments, derived from radionuclide measurements. Indeed, the fraction of OC fluxes which is not buried in the sediment is sufficient to support the benthic respiration processes.
\end{abstract}

Key words: Organic carbon; carbonates; nitrogen; settling particulate matter; Adriatic Sea; continental shelf.

Received: June 2018. Accepted: November 2018.

\section{INTRODUCTION}

The continental shelves are characterised by large amounts of suspended particulate matter, derived from various sources as the autochthonous production, rivers and terrestrial runoff. The Northern Adriatic Sea (NAd) shelf receives large riverine inputs of dissolved organic carbon, nutrients, suspended solids and associated carbonates, organic carbon, nitrogen and phosphorus (Pettine et al., 1998; Ludwig et al., 2009; Cozzi and Giani, 2011; Cozzi et al., 2012). As a result, the NAd is one of the most productive sectors of the entire Mediterranean Sea (D’Ortenzio and Ribera, 2009; Lazzari et al., 2012).

In the last decade, a shift toward a general oligotrophication of the NAd has been reported (Mozetič et al., 2010; Giani et al., 2012; Colella et al., 2016) along with an increasing trend of water acidification (Luchetta et al., 2010). Since these phenomena are expected to exacerbate in the near future and expand down to the sea bottom, a better comprehension of the benthic-pelagic coupling processes in the NAd and, in particular, the quantification of the downward particle fluxes is crucial for understanding ecosystem changes in this shallow continental shelf.

The concentration and composition of suspended particulate matter and the related downward fluxes in the NAd generally show a large spatial and temporal variability (Giani et al., 2001). The typical environmental conditions (e.g., shallow depth not exceeding $50 \mathrm{~m}$, large riverine inputs, cyclonic circulation) and the seasonal cycle determine the persistence of rather different biogeochemical processes in the water column and at the water-sediment interface (Ogrinc et al., 2003; Solidoro et al., 2009).

The most common methodology for estimating the downward flux of suspended particulate matter uses sediment traps. Even if the sediment traps deployed in shallow waters are subject to different bias due to hydrodynamic effects of the flow over the trap mouth and to the presence of fouling and swimmers (Buessler et al., 2007), these instruments remain a solid tool to date for 
estimating the particle flux from the water column to the sea floor and its temporal variability.

Due to the cyclonic circulation and to the geographic setting of river mouths, decreasing west-east and coastoffshore gradients in suspended matter concentrations, particulate organic carbon concentrations and plankton primary production are generally observed in the NAd (Gilmartin and Revelante, 1983; Smodlaka, 1986, Giani et al., 2005). Thus, our analyses considered the data obtained from a selection of sites located in three different sectors of the Northern Adriatic Sea: western coastal, eastern coastal, and offshore sectors (Fig. 1). The variables used for the analysis included the total mass flux as well as carbon, nitrogen and carbonates fluxes. We searched for and collated a large data set of downward particle fluxes measured using sediment traps in the NAd. These data, extracted from published and grey literature and partly still unpublished, were analysed to ascertain spatio-temporal scales of variability in the benthic-pelagic exchanges of this shallow area of the Adriatic Sea.

In shallow basins such as the NAd the suspended particle dynamics typically depends not only upon the allochthonous inputs, local primary production and degradation/remineralization processes, but are also largely influenced by sediment resuspension and near-bottom advective transport induced by winds and waves (Faganeli, 1989; Puškaric et al., 1992; Giani et al., 2001; Boldrin et al., 2009). Therefore, in this study the downward fluxes of organic carbon were compared with primary production in the different areas, with an estimation of primary marine fluxes of organic carbon in this basin.
To evaluate the fraction of the settling particulate organic matter, which accumulates on the seabed, the particle flux was compared with the mass accumulation rates (MAR), allowing to estimate the organic carbon potentially available for consumption by benthic organisms or chemical oxidation.

\section{METHODS}

\section{Study area}

The NAd is subject to strong seasonal variations: in winter, because of pronounced vertical instability of the water column associated with seasonal wind mixing, Po river freshwaters are mostly confined along the NAd western coast, whereas during the period of stratification the Po river plume can extend eastwards toward the Istria peninsula (Franco et al., 1992) as response to the intensity of the river discharge and to the Bora wind (Mauri et al., 2007). In the northern Adriatic Sea, major primary production variations occur along the trophic gradient due to nutrient rich freshwater discharges. The range of phytoplankton production is considerable: annual values range between 60 and $90 \mathrm{~g} \mathrm{C} \mathrm{m}^{-2} \mathrm{yr}^{-1}$ and between 130 and $210 \mathrm{~g} \mathrm{C} \mathrm{m}^{-2} \mathrm{yr}^{-1}$ for offshore and coastal waters, respectively (Pugnetti et al., 2006 and references therein).

Fluvial sediments are initially deposited on the prodelta areas with an efficient transport along the shelf (Coreggiari et al., 2001), where fine sediments are deposited mainly in a belt parallel to the western coast which get wider south of the Po prodelta (Brambati et al.,

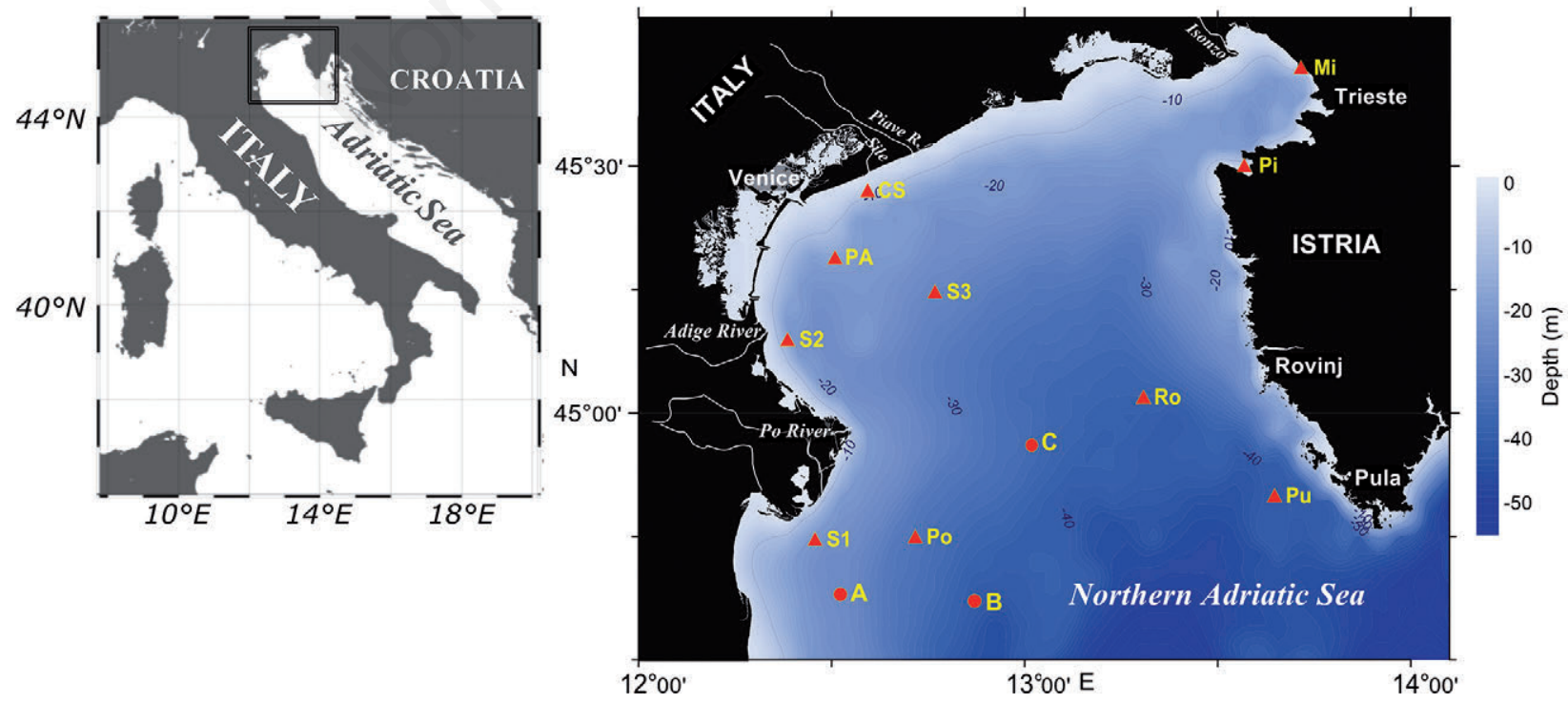

Fig. 1. Location of sediment traps deployment. Triangles indicate moored trap positions, whereas the circles represent the central position of drifting trap deployments. 
1983). In NAd shallow waters the strong hydrodynamic forcing, mainly determined by NE and SE winds, can promote sediment resuspension (Wang and Pinardi, 2002; Fox et al., 2004; Fain et al., 2007; Boldrin et al., 2009).

Mass accumulation rates in the NAd range from 0.06 to $6.6 \mathrm{~g} \mathrm{~cm}^{-2} \mathrm{y}^{-1}$ (corresponding to 0.6 to $66 \mathrm{~kg} \mathrm{~m}^{-2} \mathrm{y}^{-1}$ ) with the highest values observed in the Po and Isonzo river prodeltas (Frignani et al., 2005).

\section{Site location and sediment traps}

The sediment trap data used in this work was collected in the framework of different research projects spanning from 1982 to 2010 . We considered 10 sites with moored trap and 3 with drifting traps located in the NAd sites shown in Fig. 1, the metadata describing the trap deployments at the investigated sites are reported in Tab. 1.

In all the sites, the moored and the drifting traps were sited few meters above the bottom (bottom-traps). In 5 sites for moored and 2 for drifting traps an additional upper trap was positioned in the middle of the water column. Part of sediment-trap data have been previously published (Faganeli, 1989; Puškaric et al., 1992; Miquel et al., 1999; Giani et al., 2001; Turchetto et al., 2002), but here they have been reconsidered, re-elaborated and further discussed. Other data, collected by the authors but only partially published (Boldrin et al., 2006; Giani et al., 2003 b) or unpublished (Boldrin and De Lazzari, personal commumincation), have been utilised in this work.

The sites with moored traps can be geographically divided in western (sites PA, S1, S2, PO, CS), eastern (sites MI, PI, PU) and offshore (sites RO, S3) areas. Whereas, the drifting traps were located in western (site A) and offshore (sites B, C) areas.

A total of 374 moored trap samples were considered (327 for bottom-traps and 47 for upper-traps), 219 in western, 73 in the eastern and 82 in offshore areas. Overall, the sampled periods amounted to 3710 days for bottom-traps (western: 1598; eastern: 1588; offshore: 524

Tab. 1. Site geographic settings and sediment trap general information.

\begin{tabular}{|c|c|c|c|c|c|c|c|c|c|c|c|}
\hline \multirow[b]{2}{*}{ Area } & \multirow[b]{2}{*}{ Site } & \multirow[b]{2}{*}{ Lat. $\mathrm{N}$} & \multirow[b]{2}{*}{ Long. E } & \multirow{2}{*}{$\begin{array}{l}\text { Bottom } \\
\text { depth } \\
(\mathrm{m})\end{array}$} & \multirow{2}{*}{$\begin{array}{c}\text { Distance } \\
\text { from bottom } \\
(\mathrm{m})\end{array}$} & \multicolumn{3}{|c|}{ Sediment trap features } & \multirow[b]{2}{*}{ Deployment period } & \multirow{2}{*}{$\begin{array}{l}\text { Sampling } \\
\text { frequency } \\
\text { (days) }\end{array}$} & \multirow[b]{2}{*}{ Ref. } \\
\hline & & & & & & Type & $\begin{array}{c}\text { Surface } \\
\left(\mathrm{m}^{2}\right)\end{array}$ & $\begin{array}{l}\text { Height/Width } \\
(\mathrm{H} / \mathrm{W})\end{array}$ & & & \\
\hline \multicolumn{12}{|c|}{ Moored traps } \\
\hline \multirow{5}{*}{ 萬 } & PA & $45^{\circ} 18.93^{\prime}$ & $12^{\circ} 30.53^{\prime}$ & 16 & 2 & $\begin{array}{l}\text { Hydro-Bios Multi } \\
\text { Sediment Trap }\end{array}$ & 0.015 & 4 & $\begin{array}{c}\text { Several not } \\
\text { continuous periods } \\
\text { from } 1992 \text { to } 1995\end{array}$ & $4-99$ & (1) \\
\hline & S2 & $45^{\circ} 09.00^{\prime}$ & $12^{\circ} 23.15^{\prime}$ & 20 & 2 & $\begin{array}{c}\text { Technicap PPS } \\
4 / 3\end{array}$ & 0.05 & 4 & $\begin{array}{c}\text { Apr-Nov 1995; Feb- } \\
\text { Jul } 1996\end{array}$ & $3-7$ & (2) \\
\hline & s1 & $44^{\circ} 44.70^{\prime}$ & $12^{\circ} 27.42^{\prime}$ & 21 & $2,11\left(^{*}\right)$ & $\begin{array}{c}\text { Technicap PPS } \\
4 / 3\end{array}$ & 0.05 & 4 & Sep 1995-Jan 1996 & $2-4$ & (2) \\
\hline & cs & $45^{\circ} 27.08^{\prime}$ & $12^{\circ} 35.60^{\prime}$ & 14.5 & 3 & $\begin{array}{c}\text { Technicap PPS } \\
4 / 3\end{array}$ & 0.05 & 4 & $\begin{array}{l}\text { Dec 2003-Jan } 2005 \\
\text { with a few monthly } \\
\text { gaps; Jul-Oct2009; } \\
\text { Mar-May2010 }\end{array}$ & $6-8$ & $\begin{array}{l}\text { (3) } \\
\text { (4) }\end{array}$ \\
\hline & PO & $44^{\circ} 44.00^{\prime}$ & $12^{\circ} 43.00^{\prime}$ & 32 & $2,12\left({ }^{*}\right)$ & 4 PVC tubes & $\begin{array}{l}0.004 \\
\text { each }\end{array}$ & 8 & Jan-May 1989 & $20-30$ & (5) \\
\hline \multirow{3}{*}{ 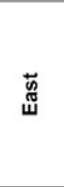 } & MI & $45^{\circ} 42.02^{\prime}$ & $13^{\circ} 42.93^{\prime}$ & 16 & 1.5 & $\begin{array}{c}\text { Technicap PPS } \\
4 / 3\end{array}$ & 0.05 & 4 & Jun 1998-Jul 2002 & $1-7$ & (6) \\
\hline & PU & $44^{\circ} 49.00^{\prime}$ & $13^{\circ} 38.30^{\prime}$ & 37 & $2,12\left({ }^{*}\right)$ & 4 PVC tubes & $\begin{array}{l}0.004 \\
\text { each }\end{array}$ & 8 & Jun-Dec 1989 & $20-30$ & (5) \\
\hline & PI & $45^{\circ} 31.00^{\prime}$ & $13^{\circ} 33.50^{\prime}$ & 16 & 1 & $\begin{array}{l}6 \text { plastic } \\
\text { cylinders }\end{array}$ & $\begin{array}{l}0.003 \\
\text { each }\end{array}$ & 5 & $\begin{array}{l}\text { Jul-Aug 1982; Jan- } \\
\text { Feb 1983; Sep 1985- } \\
\text { Jun } 1986\end{array}$ & $1-3 ; \sim 15$ & (7) \\
\hline \multirow{2}{*}{$\begin{array}{l}0 \\
\frac{0}{0} \\
\frac{1}{0} \\
0\end{array}$} & S3 & $45^{\circ} 14.75^{\prime}$ & $12^{\circ} 46.06^{\prime}$ & 29 & $4,14\left(^{*}\right)$ & $\begin{array}{l}4 \text { cylindrical } \\
\text { tubes }\end{array}$ & $\begin{array}{l}0.008 \\
\text { each }\end{array}$ & 4.5 & Jun 1992-Oct 1996 & $4-96$ & $\begin{array}{l}\text { (1) } \\
\text { (2) }\end{array}$ \\
\hline & RO & $45^{\circ} 02.40^{\prime}$ & $13^{\circ} 18.30^{\prime}$ & 37 & $2,12\left({ }^{*}\right)$ & 4 PVC tubes & $\begin{array}{l}0.004 \\
\text { each }\end{array}$ & 8 & Nov 1988-Dec1989 & $20-30$ & (5) \\
\hline \multicolumn{12}{|c|}{ Drifting traps } \\
\hline 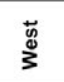 & A & $\begin{array}{l}\text { from } 44^{\circ} 35.0^{\prime} \\
\text { to } 44^{\circ} 41.0^{\prime * \star}\end{array}$ & $\begin{array}{l}\text { from } 12^{\circ} 22.1^{\prime} \\
\text { to } 12^{\circ} 40.4^{\prime}\end{array}$ & $13-30$ & $5-6,10-24\left(^{\star}\right)$ & 2 cone shaped & 0.56 each & na & $\begin{array}{l}\text { Jun 1996; Feb 1997; } \\
\text { Jun 1997; Feb } 1998\end{array}$ & $0.5-2$ & (8) \\
\hline \multirow{2}{*}{ 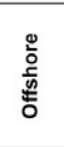 } & B & $\begin{array}{l}\text { from } 44^{\circ} 31.2^{\prime} \\
\text { to } 44^{\circ} 43.9^{\prime * *}\end{array}$ & $\begin{array}{l}\text { from } 12^{\circ} 48.6^{\prime} \\
\text { to } 12^{\circ} 55.9^{\prime} * *\end{array}$ & $33-41$ & $7-11,30-34\left(^{*}\right)$ & 2 cone shaped & 0.56 each & na & $\begin{array}{l}\text { Jun 1996; Feb 1997; } \\
\text { Jun 1997; Feb } 1998\end{array}$ & $0.5-2$ & (8) \\
\hline & C & $44^{\circ} 56.1^{\prime}$ & $13^{\circ} 01.1^{\prime}$ & 35 & 8 & $\begin{array}{c}\text { Technicap } \\
\text { PPS5/2 }\end{array}$ & 1.0 & 1.6 & Jul 1993 & $1-2$ & (9) \\
\hline
\end{tabular}

*Distance from bottom for lower and upper traps; ${ }^{* *}$ coordinates of the area of the drifting-trap deploymentReferences

(1) Boldrin, unpublished data

(2) Giani et al., 2001

(3) Boldrin et al., 2006
(4) Boldrin and De Lazzari, unpublished data

(5) Puskaric et al., 1992

(6) Giani et al., 2003a
(7) Faganeli, 1989

(8) Turchetto et al., 2002

(9) Miquel et al., 1999 
days) and to 1104 days for the upper-traps (split up in: western 231, eastern 175 and offshore 698 days).

The western sites $\mathrm{S} 1$ and $\mathrm{PO}$ are located in front of the Po river delta, whereas S2 is influenced by Adige river. These rivers represent the main freshwater loads in the NAd (average discharges $1569 \mathrm{~m}^{3} \mathrm{~s}^{-1}$ and $200 \mathrm{~m}^{3} \mathrm{~s}^{-1}$, respectively; Cozzi and Giani, 2011). Minor rivers (Sile and Piave: $41 \mathrm{~m}^{3} \mathrm{~s}^{-1}$ and $54 \mathrm{~m}^{3} \mathrm{~s}^{-1}$ average discharges, respectively; Autorità di bacino dell'Adige, 2009a and 2009b, ARPAV, 2018, Verri et al., 2018) influence the CS site. The site PA, located at about $15 \mathrm{~km}$ from venetian coast, is considered in the western area. The easternmost site (MI), in the gulf of Trieste, is affected by the Isonzo River discharge (average $82 \mathrm{~m}^{3} \mathrm{~s}^{-1}$; Cozzi et al., 2012), only during high floods. Moreover, in the eastern area we considered also other two sites (Fig. 1), one located in front of Pula (site PU; Puškaric et al., 1992), and the second in the bay of Piran, in the south-eastern part of Trieste gulf (site PI), and reported earlier by Faganeli (1989).

The site S3, located at about $40 \mathrm{~km}$ east of Venetian coast (Giani et al., 2001), and the site RO, $25 \mathrm{~km}$ off Rovinj (Puškaric et al., 1992), are considered as representative of the offshore environment. Furthermore, drifting sediment trap located inside the Po River plume (trap A) and outside of it (traps B and C) were considered. These data were obtained from the studies carried out by Turchetto and co-workers (2002) in June 1996, June 1997, February 1997, February 1998 and by Miquel and coworkers (1999) in July 1993. More information on sites and details on deployments are reported in Tab. 1 and the localisation is shown in the Fig. 1.

Different designs of the traps were used in the deployments and could affect the efficiency of the sampling device, not easy to quantify (for a complete analysis of the biases in the sediment traps use see USGOFS, 1989). However, all the traps used were cylindrical-conical type with height to width ratios (H/W) generally $\geq 4$, required for good collection efficiency under most environmental conditions (Buesseler et al., 2007).

The sampling frequency varied from 1 to 91 days. The difference in sampling timing introduces potential biases due to the fouling of the traps during prolonged absence of maintenance, though the longer sampling concerned the traps located in the offshore waters.

\section{Treatment of sediment trap samples}

The sample treatment and the analytical methods were similar in all the experiments. Collection bottles were filled with $4 \%$ formaldehyde solution of seawater collected at the same depth of the traps, buffered at $\mathrm{pH}$ 8.2 and filtered on a $0.4 \mu \mathrm{m}$ Nuclepore filter (Miquel et al., 1994). In the open cylindrical traps used in S3 and partially in PA, to minimize diffusive loss of poison during deployment and better retain the collected samples, the sampling bottles, screwed at the base of the tube, were filled with $4 \%$ formaldehyde solution of a $50 \mathrm{~g} \mathrm{~L}^{-1} \mathrm{NaCl}$ solution (USGOFS, 1989).

Samples treatment followed the methodology described in Heussner et al., 1990. The "swimmers", metazoan zooplankton that actively enter sediment traps and that do not contribute to the passive flux (Buesseler, 2007; Rizzo et al., 2009; Miquel et al., 2011), were removed manually under a dissecting microscope. To determine total mass flux (TMF) the gravimetric method was used, whereas organic carbon (OC), total carbon (TC) and total nitrogen $(\mathrm{N})$ contents were determined using high temperature gas-chromatographic $\mathrm{CHN}$ elemental analysers. Organic carbon was measured after elimination of carbonates by acidification (Hedges, 1984). Inorganic carbon content was calculated as the difference between $\mathrm{TC}$ and $\mathrm{OC}$; the carbonate content was calculated by assuming all inorganic carbon was $\mathrm{CaCO}_{3}$, using the ratio between molecular weights of $\mathrm{CaCO}_{3}$ and $\mathrm{C}$ of 8.33.

\section{Sediment-trap data analysis}

The seasonal fluxes were calculated as time-weighted means. To obtain the time-weighted flux $\left(\mathrm{F}_{\text {itw }}\right)$, each of individual flux measurements $\left(\mathrm{F}_{\mathrm{i}}\right)$ was weighted by the duration of collection (number of days - $\left.\mathrm{d}_{\mathrm{i}}\right)$ as: $\mathrm{F}_{\mathrm{itw}}=\Sigma\left(\mathrm{F}_{\mathrm{i}}\right.$ $\left.\mathrm{d}_{\mathrm{i}}\right) / \Sigma\left(\mathrm{d}_{\mathrm{i}}\right)$. This time-weighted mean gives the best (i.e., the least biased) estimate for discontinuous measurements and is used for the determination of seasonal values. Then the annual mean was calculated from the seasonal values multiplied for the season duration. The seasonal periods were defined as: winter=January-February-March; spring=April-May-June; summer=July-August-September; autumn=October-November-December.

The comparison of differences between sites and seasons was performed using the Kruskal Wallis nonparametric test. The site S1 was excluded as the data for spring were lacking. The software statistical package Statistica $^{\mathrm{TM}}$, ver. $6\left(\right.$ StatSoft $\left.^{\circledR}, \mathrm{USA}\right)$ was used.

\section{Additional data}

The flux data were integrated with available information on the composition of particulate matter and primary production of the water column and sediment properties of the sites.

The carbon export was estimated as the ratio between the OC primary downward flux and the carbon produced by phytoplankton. Annual primary production data were obtained by previous studies carried out at S1, S2 and S3 sites (Giani et al., 2001), at CS site (Boldrin et al., 2006) and in the gulf of Trieste (Fonda Umani et al., 2007).

The elemental composition of the top first $\mathrm{cm}$ of sediments $(0-1 \mathrm{~cm}$ layer) at the several stations considered was obtained from the literature and final project reports 
(Faganeli et al., 1991; Ogorelec et al., 1991; Giani et al., 1997; De Lazzari et al., 2006), whereas the data for site PA are from Boldrin (unpublished data).

The fraction of sinking carbon that definitely settles on the seabed was estimated on the basis of the carbon sedimentation rates $\left(\mathrm{OC}_{\mathrm{sed}}\right)$. In the absence of direct measurements in our experimental sites, we used the nearest mass accumulation rate (MAR) value measured on the basis of activity-depth profiles of ${ }^{210} \mathrm{~Pb}$ and reported in the literature by Frignani et al. (2005) and the OC content determined in the sediments at the study sites. For the site $\mathrm{RO}$ the mass accumulation (MAR) rates were estimated from sediment accumulation rates (SAR) on the basis of a water content of $29.9 \%$ and a density of $2.69 \mathrm{~g} \mathrm{~cm}^{-3}$.

\section{RESULTS AND DISCUSSION}

\section{Downward fluxes and composition of settling matter}

The averages of TMF and elemental composition of settling particulate matter at all the investigated sites are reported in Tab. 2.
Overall, TMF data for bottom-traps ranged between 0.05 and $293.50 \mathrm{~g} \mathrm{~m}^{-2} \mathrm{~d}^{-1}$, with an average of $22.35 \pm 40.87$ $\mathrm{g} \mathrm{m}^{-2} \mathrm{~d}^{-1}$. The downward fluxes follow the spatial trend of suspended particulate matter concentrations typically observed in the NAd (Giani et al., 2003a; Boldrin et al., $2005)$, with a clear $(p<0.01$, Mann-Whitney $U$ test $)$ increase of TMF in the coastal-western area with respect to the eastern coast and the offshore areas. The western coastal sites showed higher fluxes (mean value: $30.96 \pm 49.60 \mathrm{~g}$ $\mathrm{m}^{-2} \mathrm{~d}^{-1}$ ), whereas the eastern sites flux was on average reduced to about $1 / 3\left(11.00 \pm 15.88 \mathrm{~g} \mathrm{~m}^{-2} \mathrm{~d}^{-1}\right)$ and to $1 / 4$ in the offshore sites $\left(7.19 \pm 9.16 \mathrm{~g} \mathrm{~m}^{-2} \mathrm{~d}^{-1}\right)$, but the differences between these last two areas were not significant.

TMF in the upper-traps showed the same spatial trend of the bottom-traps, but the fluxes were about 5 time lower (average $4.63 \pm 5.79 \mathrm{~g} \mathrm{~m}^{-2} \mathrm{~d}^{-1}$; in the western area $7.25 \pm 7.24 \mathrm{~g} \mathrm{~m}^{-2} \mathrm{~d}^{-1}$; in the eastern sites $2.18 \pm 0.58 \mathrm{~g} \mathrm{~m}^{-2}$ $\mathrm{d}^{-1}$; offshore $2.09 \pm 2.13 \mathrm{~g} \mathrm{~m}^{-2} \mathrm{~d}^{-1}$ ).

The drifting-trap mass fluxes were around $0.51 \pm 0.48 \mathrm{~g}$ $\mathrm{m}^{-2} \mathrm{~d}^{-1}$, about $3 \%$ of the moored bottom-ones in the western coastal area and about $6 \%$ in the offshore. This discrepancy

Tab. 2. Daily total mass flux (TMF) and elemental composition of settling particles.

\begin{tabular}{|c|c|c|c|c|c|c|c|c|c|c|c|c|c|c|c|c|c|c|c|}
\hline & \multirow[t]{2}{*}{ Area } & \multirow[t]{2}{*}{ Site } & \multirow[t]{2}{*}{ Period } & \multicolumn{3}{|c|}{$\operatorname{TMF}\left(\mathrm{g} \mathrm{m}^{-2} \mathrm{~d}^{-1}\right)$} & \multicolumn{3}{|c|}{ OC (\%) } & \multicolumn{3}{|c|}{$\mathrm{CaCO}_{3}(\%)$} & \multicolumn{3}{|c|}{$N(\%)$} & \multicolumn{3}{|c|}{$\mathrm{OC} / \mathrm{N}(\mathrm{mol} / \mathrm{mol})$} & \multirow[t]{2}{*}{ Ref. } \\
\hline & & & & avg & $s d$ & $n$ & avg & $s d$ & $n$ & avg & $s d$ & $n$ & avg & $s d$ & $n$ & avg & $s d$ & $n$ & \\
\hline \multirow{17}{*}{ 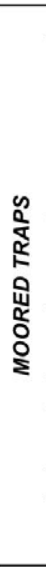 } & Bottom trap & & & & & & & & & & & & & & & & & & \\
\hline & Western & PA & annual & 20.25 & 30.08 & 39 & 4.10 & 2.66 & 14 & 34.49 & 14.95 & 14 & 0.53 & 0.40 & 14 & 9.9 & 1.9 & 14 & (1) \\
\hline & & s2 & annual & 28.99 & 50.46 & 70 & 2.51 & 0.85 & 70 & 41.72 & 7.30 & 70 & 0.32 & 0.14 & 70 & 9.6 & 2.5 & 70 & (2) \\
\hline & & s1 & annual & 31.90 & 38.32 & 33 & 2.55 & 1.71 & 33 & 21.45 & 5.09 & 33 & 0.36 & 0.27 & 33 & 8.6 & 1.1 & 33 & (2) \\
\hline & & cs & annual & 41.52 & 65.06 & 51 & 2.50 & 1.38 & 51 & 50.24 & 9.51 & 51 & 0.36 & 0.28 & 51 & 9.5 & 4.8 & 51 & $\begin{array}{l}\text { (3) } \\
\text { (4) }\end{array}$ \\
\hline & & PO & annual & 26.17 & 14.46 & 3 & 1.93 & 0.61 & 3 & 22.27 & 10.78 & 3 & na & na & na & na & na & na & (5) \\
\hline & Eastern & MI & annual & 11.37 & 16.50 & 57 & 3.71 & 1.56 & 59 & 20.29 & 5.69 & 58 & 0.54 & 0.37 & 59 & 8.6 & 1.4 & 59 & (6) \\
\hline & & PU & annual & 6.16 & 2.46 & 5 & 3.60 & 1.18 & 5 & 39.84 & 2.71 & 5 & na & na & na & na & na & na & (5) \\
\hline & & PI & annual & 12.20 & 8.50 & na & 2.50 & 1.00 & na & na & na & na & 1.00 & na & na & 8.1 & 4.2 & na & (7) \\
\hline & Offshore & S3 & annual & 6.95 & 10.29 & 48 & 4.07 & 2.00 & 28 & 28.30 & 7.83 & 28 & 0.49 & 0.24 & 28 & 10.1 & 4.0 & 28 & $(1,2)$ \\
\hline & & RO & annual & 7.89 & 4.45 & 16 & 2.65 & 0.88 & 16 & 31.46 & 3.93 & 16 & na & na & na & na & na & na & (5) \\
\hline & Upper trap & & 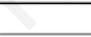 & & & & & & & & & & & & & & & & \\
\hline & Western & s1 & annual & 7.24 & 7.58 & 21 & 4.50 & 2.48 & 21 & 18.06 & 6.89 & 21 & 0.80 & 0.55 & 21 & 7.36 & 1.51 & 21 & (2) \\
\hline & & PO & annual & 7.30 & 2.40 & 2 & 4.15 & 0.64 & 2 & 32.40 & 7.21 & 2 & na & na & na & na & na & na & (5) \\
\hline & Eastern & PU & annual & 2.18 & 0.58 & 6 & 7.08 & 2.67 & 6 & 58.63 & 11.15 & 6 & na & na & na & na & na & na & (5) \\
\hline & Offshore & S3 & annual & 1.51 & 2.87 & 7 & 10.88 & 5.48 & 7 & 15.10 & 9.03 & 7 & 1.29 & 0.48 & 7 & 9.65 & 1.63 & 7 & (2) \\
\hline & & Ro & annual & 2.46 & 1.54 & 11 & 6.09 & 1.96 & 11 & 38.76 & 10.78 & 11 & na & na & na & na & na & na & (5) \\
\hline \multirow{11}{*}{ 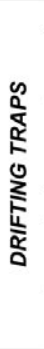 } & Bottom trap & & & & & & & & & & & & & & & & & & \\
\hline & Western & A & spring & 0.07 & 0.04 & 2 & 23.27 & 11.41 & 2 & 10.46 & 14.18 & 2 & 3.70 & 1.74 & 2 & 7.30 & 0.14 & 2 & (8) \\
\hline & & A & winter & 1.68 & 2.06 & 2 & 4.04 & 2.03 & 2 & 39.33 & 26.27 & 2 & 0.70 & 0.50 & 2 & 7.40 & 1.84 & 2 & (8) \\
\hline & Offshore & B & spring & 0.11 & 0.13 & 2 & 22.51 & 22.95 & 2 & 30.67 & 24.79 & 2 & 3.22 & 3.23 & 2 & 8.10 & 0.28 & 2 & (8) \\
\hline & & B & winter & 1.17 & 0.23 & 2 & 2.24 & 0.98 & 2 & 35.57 & 8.55 & 2 & 0.31 & 0.14 & 2 & 8.35 & 0.07 & 2 & (8) \\
\hline & & C & spring & 0.13 & na & 1 & 9.06 & na & 1 & 2.44 & na & 1 & 1.26 & na & 1 & 8.40 & na & 1 & (9) \\
\hline & Upper trap & & & & & & & & & & & & & & & & & & \\
\hline & Western & A & spring & 0.29 & 0.25 & 2 & 18.79 & 12.21 & 2 & 1.85 & na & 1 & 2.12 & 0.85 & 2 & 9.80 & 2.83 & 2 & (8) \\
\hline & & A & winter & 0.24 & 0.33 & 2 & 10.73 & 0.70 & 2 & 6.71 & na & 1 & 1.35 & 0.36 & 2 & 9.75 & 3.18 & 2 & (8) \\
\hline & Offshore & B & spring & 0.06 & 0.001 & 2 & 20.56 & 9.40 & 2 & 23.57 & 30.59 & 2 & 3.86 & 2.47 & 2 & 6.70 & 1.41 & 2 & (8) \\
\hline & & B & winter & 0.02 & na & 1 & 21.82 & na & 1 & 28.64 & na & 1 & 3.95 & na & 1 & 6.50 & na & 1 & (8) \\
\hline
\end{tabular}

avg, average; sd, standard deviation; n, number of observations, $\mathrm{OC}$, organic carbon; $\mathrm{CaCO}_{3}$, carbonates; $\mathrm{N}$, nitrogen.

References

(1) Boldrin, unpublished data

(2) Giani et al., 2001

(3) Boldrin et al., 2006
(4) Boldrin and De Lazzari, unpublished data

(5) Puskaric et al., 1992

(6) Giani et al., 2003a
(7) Faganeli, 1989

(8) Turchetto et al., 2002

(9) Miquel et al., 1999 
could be considered very great but we must consider the difference in the methodology, that could reduce the lateral supply and the difference in sampling period, as more widely discussed in Buesseler et al. (2007). The POC fluxes in the drifting traps ranged from 1 to $82 \mathrm{mg} \mathrm{m}^{-2} \mathrm{~d}^{-1}$. The highest values are comparable to the highest ones reported for the Mediterranean Sea in the Alboran Sea (Ramondnec et al., 2016). The mean particulate nitrogen fluxes were 3fold higher than those measured in the NW Mediterranean Sea (Marty et al., 2009). The offshore fluxes of OC were $13 \mathrm{mg} \mathrm{m}^{-2} \mathrm{~d}^{-1}$, less than half of those measured by the more coastal traps, and more than 10-fold lower by the fluxes measured with the same approach in the gulf of Trieste (Wassmann et al., 1999). The OC and $\mathrm{N}$ contents in the settling matter of bottom traps ranged from 0.71 to $11.30 \%$ (average $3.01 \pm 1.57 \%$ ) and from 0.06 to $2.21 \%$ (average $0.42 \pm 0.29 \%$ ), respectively. In the upper-traps the percentages of $\mathrm{OC}$ and $\mathrm{N}$ on TMF were about double than in the bottom ones, being on average $6.14 \pm 3.63 \%$ for OC and $0.92 \pm 0.57 \%$ for $\mathrm{N}$.

At all sites, the OC content of settling particles was linearly correlated with that of $\mathrm{N}(\mathrm{P} \leq 0.0001)$. In the uppertraps the $\mathrm{OC} / \mathrm{N}$ molar ratio derived from the linear regression slope was 7.12, whilst in bottom-traps $\mathrm{OC} / \mathrm{N}$ was 9.86. This difference could be attributable to a higher contribution of plankton in the upper trap than in the bottom one, where also resuspended matter can easily settle.

Carbonates, which constituted from 2 to $59 \%$ of the total mass flux, are provided by the minerals carried by rivers (calcite and dolomite), by calcareous planktonic organisms as coccolithophorids (Turchetto et al., 2002; Bernardi Aubry et al., 2004) or foraminifera, and by resuspension of bottom sediments containing biogenic carbonates (calcite and aragonite) from shell and skeleton debris, coralline algae (Ogorelec et al., 1991) and benthic foraminifera (Puskaric et al., 1992). Calcite and dolomite minerals are mostly carried in the NAd by Isonzo, Piave, Tagliamento, Brenta and Adige rivers (Brondi et al., 1979), whereas the Po River carries no dolomite, less calcite and higher amounts of silica particles. The higher content of carbonates (Mann-Whitney $\mathrm{U}$ test, $\mathrm{P}<0.05$ ), found in areas influenced by Adige and Brenta Rivers (site S2), by Piave (site CS) and by the outlets of the Venice lagoon (site PA), reflect the contribution of calcite and dolomite carried by the rivers with drainage basin including the dolomitic Alps, as also shown by the distribution of carbonates in the surface sediments of the NAd (Ravaioli et al., 2003). High carbonate concentrations can be found also off the Istria peninsula (NE Adriatic Sea) where the sediments contain more than $50 \%$ of carbonates originating from Mesozoic sediments of Dinaric Alps (Brambati et al., 1973). However, the elevated carbonate content in the trap material at PU site was likely due to a high recent biogenic contribution to the deposition of carbonates (Puskaric et al., 1992).
The data obtained from sediment trap located at the site MI apparently do not support an important role of the Isonzo River as a carrier of carbonates. This incongruence is likely to be attributable to the fact that the site MI is located far from the prodelta, in a coastal zone where the carbonates in the sediments are less than 30\% (Ogorelec et al., 1991). Furthermore, the hydrological circulation in the gulf of Trieste is characterized, generally, by an inflow SW-NE current determining a cyclonic circulation at the sea bottom in all seasons (Bogunović and Malačič, 2009; Malačič and Petelin, 2009), preventing the direct supply of Isonzo sediments to the trap-site.

OC and $\mathrm{N}$ content ( $\%$ of dry weight) were inversely and exponentially correlated with TMF (Fig. 2 A,B; Fig. S1). Such a "dilution effect" of OC and N within the TMF, early reported for the site S1 (Matteucci et al.,1997) and observed also in other areas (e.g., in NE-Mediterranean by Stavrakakis et al., 2000; in southern Adriatic by Langone et al., 2016; in Antarctica by Tesi et al., 2012), could be related to the increase of the mineral fraction. This could be the result of OC- and N-depleted resuspended sediments captured by the traps, as well as/or of an advective transport of riverine particulate matter (Pettine et al., 1998). On the other hand, carbonates increase with TMF at sites S1, S2 and PA, suggesting that the above-mentioned dilution effect is most likely due to carbonate rich particles collected by the traps. The OC/N ratio increases with TMF, according to a power fit of the type $\mathrm{OC} / \mathrm{N}=\mathrm{a}(\mathrm{TMF})^{\mathrm{b}}$ at sites $\mathrm{S} 1, \mathrm{~S} 2$ and CS (Fig. 2), possibly due to the resuspension of bottom sediments which have higher OC/N molar ratios (Tab. 3).

The fittings reported in Fig. 2 are in some cases asymptotic, then $\mathrm{Y}$ values tend to a given limit and this asymptotic limit was compared with the corresponding content of surficial sediments (Tab. 3). The asymptotic values differed for less than $10 \%$ from the contents of carbonates whereas for OC and $\mathrm{N}$ (only exception site $\mathrm{S} 1$ ) the estimated contents in settling matter were generally from 1.5- to 7-fold higher than those in the sediment (Tab. 3). These differences could be due to the degradation of labile organic matter, taking place during sediment accumulation, with respect to a more conservative component as the carbonates.

In the settling matter collected by the drifting traps the chemical composition showed a higher content of organic carbon ( $14.78 \pm 8.31 \%$ on average) and nitrogen $(2.28 \pm 1.43 \%$ on average) with respect to the moored traps which had an OC content of $4.19 \pm 2.33 \%$ and $\mathrm{N}$ content of $0.63 \pm 0.41 \%$ (Tab. 2). The drifting traps in offshore waters were less influenced by resuspended sediments and riverine particulate matter as shown by the lower $\mathrm{OC} / \mathrm{N}$ ratio $(7.6 \pm 0.9$ on average). This can be related to the short deployment period and the calm weather required during the experiments, conditions which limit particle resuspension. These ratios fall in the 
range of the data reported for the eastern Mediterranean Sea by Ramondenc et al. (2016). The high variability of the carbonate content could be due to two opposing processes: a lower contribution of resuspended sediments and a higher contribution of the settling of coccolithoforids in offshore waters which can be important especially during winter (Godrijan, 2018; Viličić et al, 2009).

\section{Seasonal and annual fluxes}

The seasonal settling fluxes for total particles, organic carbon, nitrogen and carbonates, calculated as timeweighted averages, are showed in Fig. 3.

We tested spatial and temporal differences in the fluxes, using the non-parametric ANOVA-Kruskal-Wallis test, considering, separately, 2 factors: sites and seasons (Tab. 4). Results of these tests showed that the effect of the site is significant for all parameters except for OC flux, whereas the seasons affect all the dependent variables except the $\mathrm{CaCO}_{3}$ content.

The highest fluxes occur, with a few exceptions for $\mathrm{OC}$ and $\mathrm{N}$ fluxes, in winter or autumn (Fig. 3). In those sites, as S1 and S2, directly influenced by the greater rivers TMF in winter were up to 9.6-fold higher than in summer. A similar difference is observed also in the

Tab. 3. Mean composition and $\mathrm{OC} / \mathrm{N}$ molar ratio of surface sediments, sediment (SAR) and mass accumulation (MAR) rates.

\begin{tabular}{|c|c|c|c|c|c|c|c|}
\hline Site & $\begin{array}{l}\text { OC } \\
\%\end{array}$ & $\begin{array}{c}\mathrm{CaCO}_{3} \\
\%\end{array}$ & $\begin{array}{l}\mathrm{N} \\
\%\end{array}$ & $\begin{array}{c}\mathrm{OC} / \mathrm{N} \\
\mathrm{mol} / \mathrm{mol}\end{array}$ & $\begin{array}{l}\text { SAR } \\
\mathrm{cm} \mathrm{y}^{-1}\end{array}$ & $\begin{array}{c}\text { MAR } \\
\mathrm{g} \mathrm{cm}^{-2} \mathrm{y}^{-1}\end{array}$ & Ref. \\
\hline \multicolumn{8}{|c|}{ Western } \\
\hline PA & 0.11 & 53.58 & 0.02 & 6.41 & 0.27 & 0.36 & $(1,2)$ \\
\hline S2 & 0.99 & 51.90 & 0.11 & 10.79 & 0.6 & 0.56 & $(1,3)$ \\
\hline s1 & 1.39 & 25.42 & 0.17 & 9.56 & na & 0.60 & $(1,3)$ \\
\hline cs & 0.55 & 58.48 & 0.06 & 10.69 & 0.32 & 0.40 & $(1,4)$ \\
\hline PO & 1.25 & 30.88 & 0.154 & 9.48 & 0.16 & 0.20 & $(1,3)$ \\
\hline \multicolumn{8}{|c|}{ Eastern } \\
\hline MI & 1.09 & 22.35 & 0.12 & 10.50 & 0.12 & 0.13 & $(5,6)$ \\
\hline $\mathrm{PI}$ & 1.04 & 29.00 & 0.18 & 6.74 & 0.1 & 0.11 & $(5,7)$ \\
\hline \multicolumn{8}{|c|}{ Offshore } \\
\hline S3 & 0.32 & 33.68 & 0.04 & 9.75 & 0.13 & 0.16 & $(1,3)$ \\
\hline RO & 0.29 & 25.74 & 0.036 & 9.43 & 0.003 & $0.004^{*}$ & $(3,7)$ \\
\hline
\end{tabular}

\section{References}

(1) Frignani et al. 2005

(2) Boldrin, unpub. data

(3) Giani et al., 1997

(4) Boldrin and De Lazzari, unpub data

(5) Faganeli et al., 1991

(6) Giani et al., 2003

(7) Ogorelec et al., 1991
A
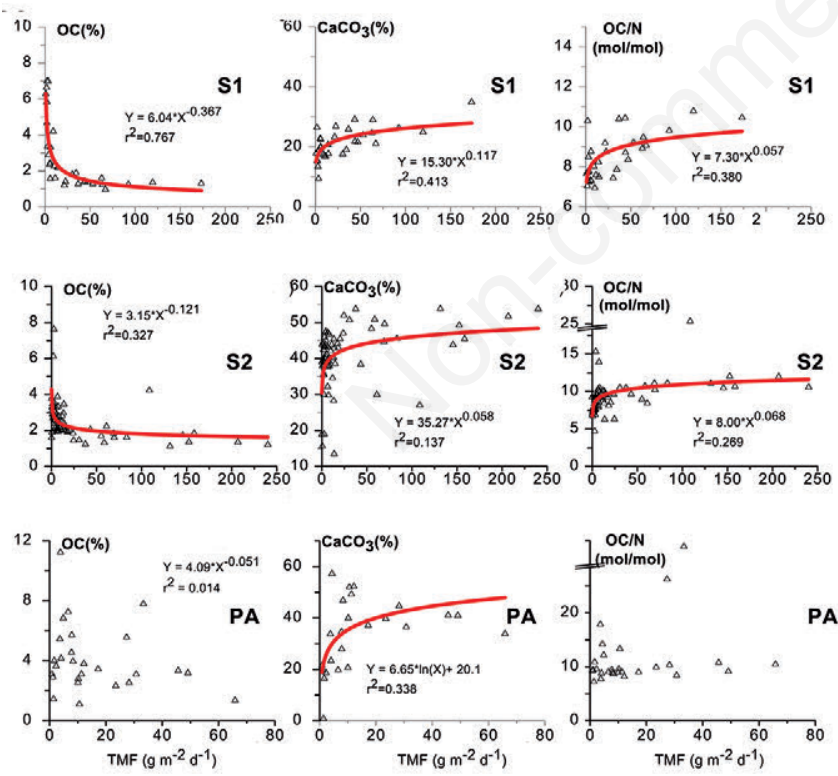

B
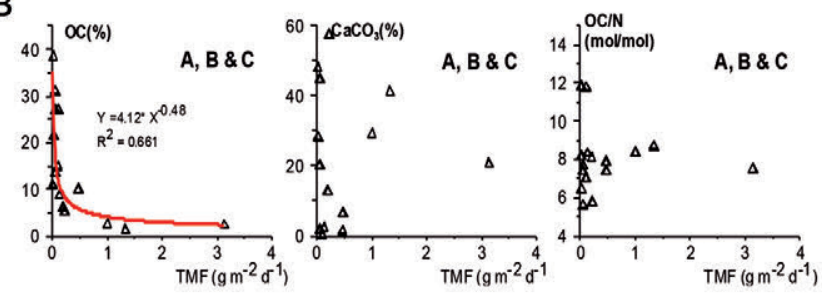
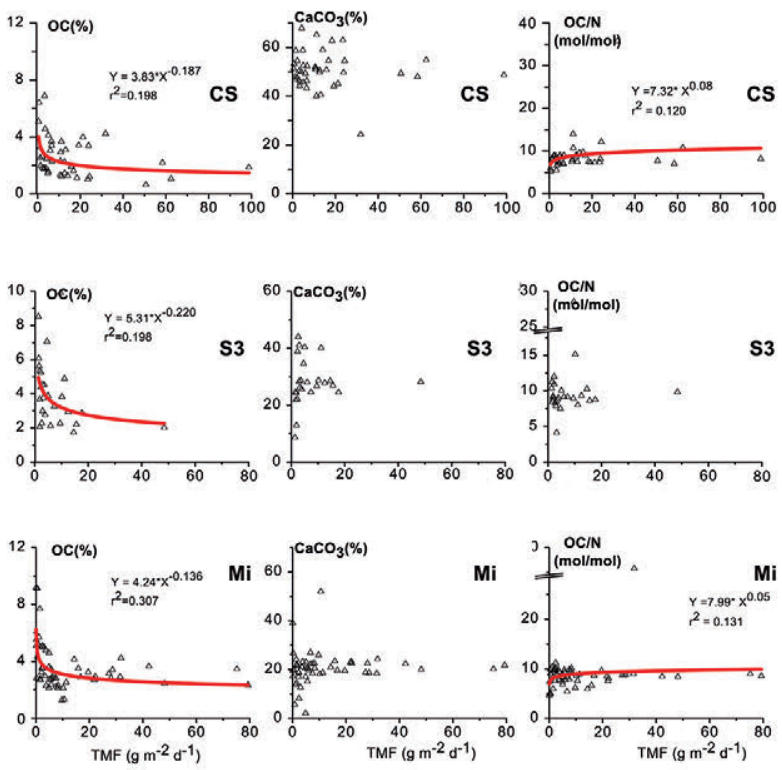

Fig. 2. A) Organic carbon and calcium carbonate content, and $\mathrm{OC} / \mathrm{N}$ molar ratio relationships with total mass fluxes for the sites $\mathrm{S} 1, \mathrm{~S} 2, \mathrm{PA}, \mathrm{CS}, \mathrm{S} 3$ and $\mathrm{Mi}$; the best fits are represented by red lines. B) Organic carbon content (\%), calcium carbonate content $(\%)$, and $\mathrm{OC} / \mathrm{N}$ molar ratio relationships with total mass fluxes for the drifting traps at A, B and C sites; the best fits are represented by red lines. 
organic carbon and nitrogen fluxes which were up to about 5.5 times higher in winter than in summer.

To further assess the extent of seasonal variability of the investigated fluxes, the seasonality index (SI), proposed by Berger and Wefer (1990) and Lampitt and Antia (1997), was calculated for sites S2, PA and RO, for all of which almost complete annual time series were available. SI is defined as the time (in days) needed for the deposition of $50 \%$ of the total matter sinking in one year after the ranking of the data (Fig. 4). SI for TMF varied from 26 days in site S2, to 66 in PA and up to 111 days in RO, and from 27 to 137 days for the OC flux in $\mathrm{S} 2$ and RO sites (the data from PA are not sufficient to complete this calculation). According to the classification proposed by Berger and Wefer (1990), the SI values allow us to define the export "strongly seasonal to pulsed" in western coastal area, since about $50 \%$ of the annual deposition settles within 1-2 months. This value is considered characteristic of areas were the sedimentation is related to events occurring at seasonal scale (riverine discharges, phytoplankton blooms) and occasional events (such as storms) strongly influence the fluxes of settling sediments in NAd. In the more oligotrophic offshore area (site RO) the $50 \%$ of sedimentation occurred in about 4-5 months and the flux appears more constant during the year.

The annual fluxes obtained from bottom traps and calculated from the seasonal weighted mean (Tab. 5), ranged from 2763 to $14447 \mathrm{~g} \mathrm{~m}^{-2} \mathrm{y}^{-1}$ for total mass flux, from 66 to $236 \mathrm{~g} \mathrm{OC} \mathrm{m}^{-2} \mathrm{y}^{-1}$ for organic carbon, from 12 to $42 \mathrm{~g} \mathrm{~N} \mathrm{~m}^{-2} \mathrm{y}^{-1}$ for nitrogen and from 861 to $7525 \mathrm{~g} \mathrm{~m}^{-2} \mathrm{y}^{-1}$ for calcium carbonates. The lowest fluxes were observed in the offshore area, whereas the highest occurred in the western sites located in front of the river mouths. The high fluxes measured in the western site CS could be due not only to the riverine particulate deposition but also to the presence of the artificial barriers close to the sampling site (Zennaro et al., 2006). It is known that the artificial reef,
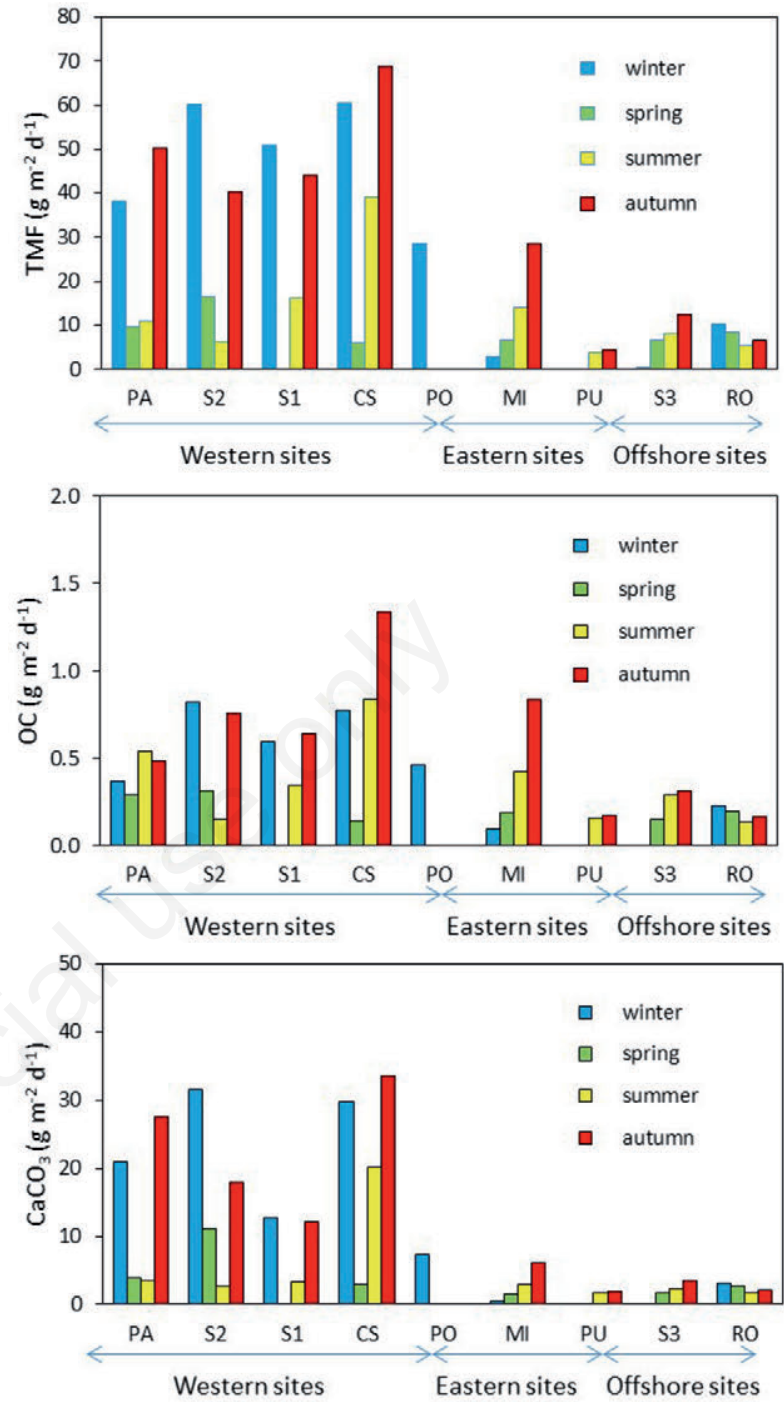

Fig. 3. Time-weighted seasonal averages of settling fluxes for total particles (TMF), organic carbon (OC) and calcium carbonates $\left(\mathrm{CaCO}_{3}\right)$ in bottom-traps.

Tab. 4. Non-parametric ANOVA-Kruskal-Wallis tests on bottom-trap fluxes and composition (\%), considering 2 independent factors: sites and seasons.

\begin{tabular}{llcccc}
$\begin{array}{l}\text { Dependent } \\
\text { Variable }\end{array}$ & $\begin{array}{l}\text { Independent variable: } \\
\text { Kruskal-Wallis test }\end{array}$ & Site & \multicolumn{2}{l}{$\begin{array}{l}\text { Independent variable: } \\
\text { Kruskal-Wallis test }\end{array}$} & $\begin{array}{c}\text { Season } \\
P\end{array}$ \\
\hline TMF & $\mathrm{g} \mathrm{m}^{-2} \mathrm{~d}^{-1}$ & $\mathrm{H}(8, \mathrm{~N}=323)=36.98$ & 0.0000 & $\mathrm{H}(3, \mathrm{~N}=323)=26.15$ & 0.0000 \\
$\mathrm{OC}$ & $\mathrm{g} \mathrm{m}^{-2} \mathrm{~d}^{-1}$ & $\mathrm{H}(8, \mathrm{~N}=276)=12.92$ & 0.1147 & $\mathrm{H}(3, \mathrm{~N}=323)=19.33$ & 0.0002 \\
$\mathrm{OC}$ & $\%$ & $\mathrm{H}(8, \mathrm{~N}=280)=58.60$ & 0.0000 & $\mathrm{H}(3, \mathrm{~N}=323)=43.59$ & 0.0000 \\
$\mathrm{CaCO}_{3}$ & $\mathrm{~g} \mathrm{~m}^{-2} \mathrm{~d}^{-1}$ & $\mathrm{H}(8, \mathrm{~N}=275)=42.12$ & 0.0000 & $\mathrm{H}(3, \mathrm{~N}=322)=20.01$ & 0.0002 \\
$\mathrm{CaCO}_{3}$ & $\%$ & $\mathrm{H}(8, \mathrm{~N}=279)=192.39$ & 0.0000 & $\mathrm{H}(3, \mathrm{~N}=322)=0.37$ & 0.9461 \\
$\mathrm{~N}$ & $\mathrm{~g} \mathrm{~m}^{-2} \mathrm{~d}^{-1}$ & $\mathrm{H}(5, \mathrm{~N}=251)=11.44$ & 0.0433 & $\mathrm{H}(3, \mathrm{~N}=251)=19.70$ & 0.0002 \\
$\mathrm{~N}$ & $\%$ & $\mathrm{H}(5, \mathrm{~N}=255)=43.17$ & 0.0000 & $\mathrm{H}(3, \mathrm{~N}=255)=55.45$ & 0.0000 \\
\hline
\end{tabular}



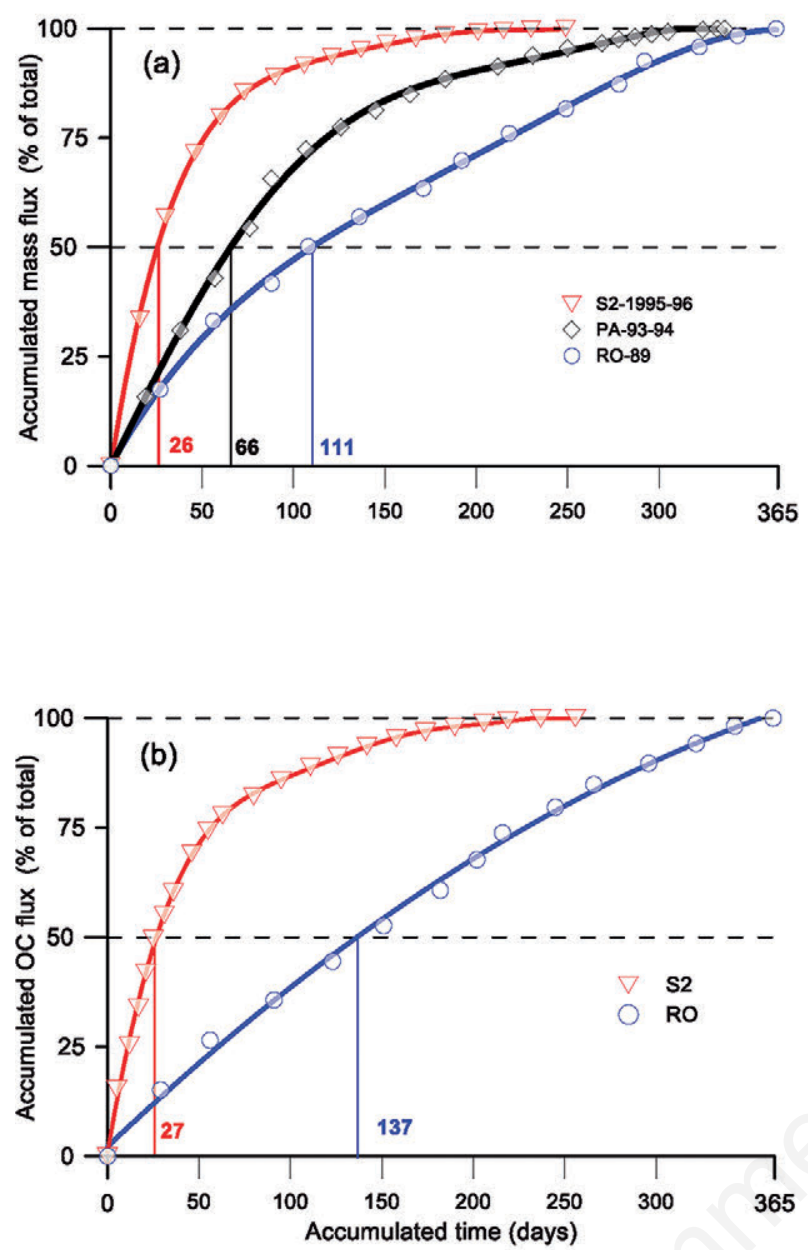

Fig. 4. Seasonal Index (SI) for accumulated total mass flux (a) and OC flux (b) for sites S2 (period June 1995-March 996), PA (period June 1993-June 1994) and RO (period JanuaryDecember 1989). The relative time values (in days) for $50 \%$ of accumulated fluxes for each parameter are reported. modifying the hydrodynamic of the area, could increase the turbulence caused by storm events and enhance the resuspension processes (Ambrose and Anderson, 1990; Falcão et al., 2009). As the CS station is shallower than the other western stations, the energy due to wind stress reaching the bottom is higher and, therefore, it generates elevated resuspended fluxes, as also evidenced by the higher values of the $\mathrm{OC}_{\mathrm{r}} / \mathrm{OC}$ ratio (Tab. 6). The higher annual carbonate fluxes in CS and S2 sites indicate a contribution of the riverine suspended matter discharged from the Piave and from Adige rivers, respectively, whose drainage basins include carbonate areas (Ravaioli et al., 2003).
Tab. 5. Annual fluxes of particulate matter, organic carbon, carbonates and nitrogen in the bottom traps. Where the seasonal data was lacking in the computation of the annual fluxes, the value was estimated as the average of the other available values.

\begin{tabular}{lcccc}
\hline \multicolumn{1}{c}{ Site } & $\begin{array}{c}\text { TMF } \\
\mathrm{g} \mathrm{m}^{-2} \mathrm{y}^{-1}\end{array}$ & $\begin{array}{c}\text { OC } \\
\mathrm{g} \mathrm{C} \mathrm{m}^{-2} \mathrm{y}^{-1}\end{array}$ & $\begin{array}{c}\mathrm{CaCO}_{3} \\
\mathrm{~g} \mathrm{~m}^{-2} \mathrm{y}^{-1}\end{array}$ & $\begin{array}{c}\mathbf{N} \\
\mathrm{g} \mathrm{N} \mathrm{m}^{-2} \mathrm{y}^{-1}\end{array}$ \\
\hline Western & & & & \\
PA & 9920 & 154 & 5110 & 16 \\
S2 & 11232 & 187 & 5777 & 22 \\
S1 & 13745 & 198 & 3545 & 25 \\
CS & 14447 & 236 & 7525 & 30 \\
\hline Eastern & & & & \\
MI & 4693 & 141 & 1009 & 20 \\
PI & 4435 & 199 & $\mathrm{na}$ & 42 \\
\hline Offshore & \multicolumn{5}{c}{} & \\
S3 & 3621 & 108 & 898 & 12 \\
RO & 2763 & 66 & 861 & $\mathrm{na}$ \\
\hline
\end{tabular}

na, not availble

Tab. 6. Gross $(\mathrm{OC})$, resupended+riverine $\left(\mathrm{OC}_{\mathrm{r}}\right)$ and primary $\left(\mathrm{OC}_{\mathrm{p}}\right)$ annual fluxes of organic carbon compared to primary production (PP) and organic carbon sedimentation $\left(\mathrm{OC}_{\mathrm{sed}}\right)$, calculated from mass accumulation rates.

\begin{tabular}{|c|c|c|c|c|c|c|c|c|c|c|c|}
\hline Site & 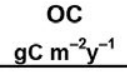 & $\begin{array}{c}\mathrm{OC}_{\mathrm{r}} \\
\mathrm{gC} \mathrm{m}^{-2} \mathrm{y}^{-1} \\
\end{array}$ & $\begin{array}{c}O C_{p} \\
g C m^{-2} y^{-1} \\
\end{array}$ & Ref. & $\begin{array}{c}\mathrm{OC}_{\mathrm{r}} / \mathrm{OC} \\
\% \\
\end{array}$ & $\begin{array}{c}P P \\
\mathrm{gC} \mathrm{m}^{-2} \mathrm{y}^{-1} \\
\end{array}$ & Ref. & $\begin{array}{c}\text { OC }_{\mathrm{p}} / \mathrm{PP} \\
\% \\
\end{array}$ & $\begin{array}{c}\mathrm{OC}_{\text {sed }} \\
\mathrm{gC} \mathrm{m}^{-2} \mathrm{y}^{-1}\end{array}$ & $\begin{array}{l}O C-O C_{\text {sed }} \\
\mathrm{gC} \mathrm{m}^{-2} \mathrm{y}^{-1}\end{array}$ & Ref. \\
\hline \multicolumn{12}{|c|}{ Western } \\
\hline PA & 154 & 124 & 30 & (1) & 81 & na & na & $\mathrm{n}$ a & 4 & 150 & (8) \\
\hline S2 & 187 & 139 & 48 & $(1,2)$ & 74 & 376 & (4) & 13 & 56 & 131 & $(2,4)$ \\
\hline S1 & 198 & 154 & 44 & $(1,2)$ & 78 & 579 & (4) & 8 & 83 & 115 & $(2,4)$ \\
\hline $\mathrm{CS}$ & 236 & 196 & 40 & (1) & 83 & 121 & (5) & 33 & 22 & 214 & (9) \\
\hline \multicolumn{12}{|c|}{ Eastern } \\
\hline $\mathrm{Mi}$ & 141 & 102 & 39 & (1) & 72 & 233 & (6) & 17 & 15 & 127 & $(10,11)$ \\
\hline $\mathrm{Pi}$ & 199 & 179 & 20 & (3) & 90 & 50 & $(7,8)$ & 40 & 11 & 188 & (12) \\
\hline \multicolumn{12}{|c|}{ Offshore } \\
\hline S3 & 108 & 87 & 21 & $(1)$ & 81 & 80 & (9) & 26 & 5 & 103 & $(2,4)$ \\
\hline \multicolumn{12}{|c|}{ References } \\
\hline \multicolumn{3}{|c|}{ (1) This work } & \multicolumn{3}{|c|}{ (4) Giani et al., 1999} & \multicolumn{3}{|c|}{ (7) Faganeli et al., 1991} & \multicolumn{3}{|c|}{ (10) Giani et al., 2003} \\
\hline \multicolumn{3}{|c|}{ (2) Giani et al., 2001} & \multicolumn{3}{|c|}{ (5) Boldrin et al., 2006} & \multicolumn{3}{|c|}{ (8) Bertruzzi et al., 1997} & (11) & \multicolumn{2}{|c|}{ Giani et al., 1997} \\
\hline \multicolumn{3}{|c|}{ (3) Faganeli, 1989} & \multicolumn{3}{|c|}{ (6) Fonda et al., 2007} & \multicolumn{3}{|c|}{ (9) Pugnetti et al., 2006} & (12) & \multicolumn{2}{|c|}{ Ogorelec et al., 1991} \\
\hline
\end{tabular}


The annual TMF estimated in the northern part of the Trieste Gulf (4693 $\mathrm{g} \mathrm{m}^{-2} \mathrm{y}^{-1}$, site MI) is close to the flux reported in the south-eastern part of the Gulf (site PI) by Faganeli (1989). More generally, the annual OC fluxes in the whole NAd are up to two-three order of magnitude higher than those of other Mediterranean areas. The OC fluxes at southern Adriatic Pit were estimated in $3.3 \mathrm{~g} \mathrm{C}$ $\mathrm{m}^{-2}$ year $^{-1}$ and at northern Ionian in $2.4 \mathrm{~g} \mathrm{C} \mathrm{m}^{-2}$ year ${ }^{-1}$, both at $150 \mathrm{~m}$ depth (Boldrin et al., 2002). Low value (4.8 $\mathrm{g} \mathrm{C} \mathrm{m}^{-2}$ year $^{-1}$ ) was observed also in Ligurian Sea at 80 $\mathrm{m}$ depth (Miquel et al., 1994).

The higher fluxes observed in NAd are reasonably correlated with the high productivity of the basin (Pugnetti et al., 2006) and with the presence of elevated riverine inputs (Cozzi and Giani, 2011). In addition, the shallow water of the basin (on average $35 \mathrm{~m}$; Lipizer et al., 2014) increases the potential effects of resuspension and sediment lateral transport.

\section{Resuspension and riverine contributions}

As already pointed out, the resuspension and sediment transport processes assume high relevance on the particle vertical fluxes in the NAd. These processes are related to the interaction between the general circulation of the water masses and the shallow bathymetry of the basin (Fain et al., 2007). Moreover, the wind stress can cause resuspension and southward transport of bottom sediments, as observed during the NE-bora wind events (Wang et al., 2007; Boldrin et al., 2009), or when elevated wave heights resuspend sediments at shallow sites (Giani et al., 2001).

Then, the particles collected by the sediment-traps can derive from different processes and have different origin. End members mixing models based on $\mathrm{OC} / \mathrm{N}$ ratio and the stable carbon isotopic composition $\left(\delta^{13} \mathrm{C}_{\mathrm{OC}}\right)$ have been frequently used in the NAd to identify the sources of organic matter in the suspended and sedimentary matter (Faganeli et al., 1988; Boldrin et al., 2005; Tesi et al., 2007; Giani et al., 2009).

In this study, to estimate the fraction that could attributed to biological production (primary flux) and those due to resuspension and transport of bottom sediment (secondary sedimentation), a label approach based on two-end members mixing was applied, according to the methodology proposed by Gasith (1975) and previously applied in the Adriatic Sea (Faganeli et al., 1989; Matteucci et al., 1997; Giani et al., 2001). For this purpose, N/OC was selected to distinguish resuspended sediments and/or riverine settling matter from autochthonous settling organic matter of planktonic origin (Perdue et al., 2007). Organic matter derived from terrestrial and marsh vascular plants is typically depleted in nitrogen $(\mathrm{N} / \mathrm{OC}<0.07)$, whereas marine phytoplankton, zooplankton and bacterioplankton are characterised by higher nitrogen content (N/OC >0.13) (Goñi and Hedges, 1995; Goñi et al., 2000).

To estimate the resuspended plus the allochthonous organic matter, the N/OC end members were selected for each site as they lie in different sedimentary environments. As end member representative of resuspension we considered the N/OC lower ratio ( 0.02 percentile of available data for each sediment trap) measured in settling matter (N/OC end members ranged from 0.07 to 0.09 ). As end member representative of marine particulate matter we used the $98^{\text {th }}$ percentile of $\mathrm{N} / \mathrm{OC}$ ratios in particulate suspended matter (N/OC end members ranged from 0.17 to 0.24 ). Then, the estimated resuspended or allochthonous matter transported by rives $\left(\mathrm{OC}_{\mathrm{r}}\right)$ on an annual basis (Tab. 6) ranged from 72 to $90 \%$ of the total particulate organic carbon fluxes. Therefore, as observed in previous studies (Matteucci et al., 1997; Giani et al., 2001), the dominant part of the fluxes in the NAd can be attributed to resuspension processes or riverine inputs of allochthonus particulate organic matter.

\section{Organic carbon export and carbon accumulation in the sediments}

The export of autochthonous-primary organic carbon $\left(\mathrm{OC}_{\mathrm{P}}\right)$, calculated as the difference between $\mathrm{OC}$ and $\mathrm{OC}_{\mathrm{r}}$, was compared with the available data of primary production (Tab. 6), and the exported fraction ranged from 8 to $40 \%$. The higher export corresponded to the site with lowest primary production (sites CS, PI and S3), whereas the lowest occurred in the most productive areas near the Po and Adige rivers (i.e. sites S1 and S2, respectively; Fig. 5). In these sites, even if the production is higher due to the removal of nutrient limitation, the export appears lower for the presence of elevated lateral advection and, probably, because of an intense degradation of the organic matter

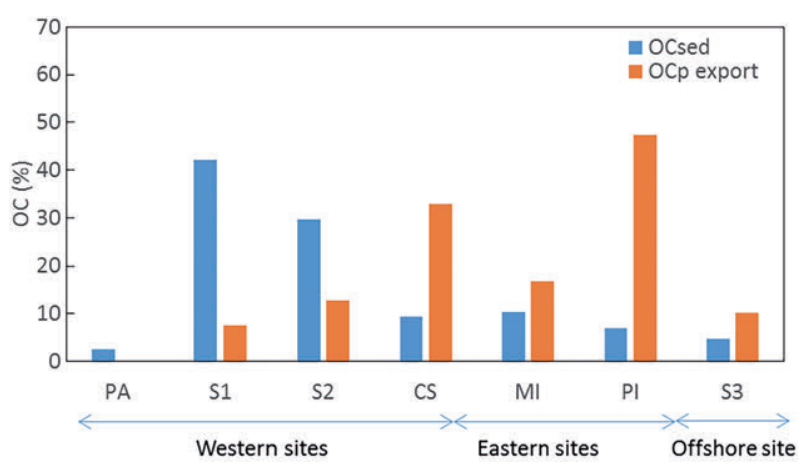

Fig. 5. Primary organic carbon exported toward the sediment with respect to primary production $\left(\mathrm{OC}_{\mathrm{p}}\right.$ export, expressed as percentage) and fraction of settled organic carbon $\left(\mathrm{OC}_{\mathrm{sed}}\right.$, expressed as percentage) with respect to the gross organic carbon flux measured in the bottom traps. 
due to high bacterial activities (Puddu et al., 1998; Giani et al., 1999). Moreover, the data and satellite images (Brando et al., 2015) indicate that the influence of the riverine input on site CS is lower than in $\mathrm{S} 1$ and $\mathrm{S} 2$, and this could be likely due to the different discharges of rivers: Po $>>$ Adige $>$ Piave $>$ Sile.

The organic carbon settling fluxes, as determined with the bottom sediment traps, were from 2 to 39 -fold higher than the organic carbon ones, calculated from mass accumulation rates at all the sites (Tab. 6). This implies that, at all sites, a relevant fraction of the settling organic matter is not buried, rather is consumed by benthic organisms, decomposed or advected to other areas. As shown in Fig. 5, the highest $\%$ of the OC flux settles in the sediments near the Po river (site S1) and Adige river (site S2).

The mass accumulation rate (MAR) integrate the sedimentation over years and, therefore, when it is converted in flux of organic carbon, it does not reflect the deposition of the labile fraction of organic matter, which could be respired or consumed by benthic organisms on a time scale of weeks or days (Giordani et al., 2002). Comparing the $\mathrm{OC}$ flux excess $\left(\mathrm{OC}-\mathrm{OC}_{\mathrm{sed}}\right)$ with the annual carbon mineralized at the sediment water - interface in the western coastal NAd, which falls in the range $54-89 \mathrm{gC}$ $\mathrm{m}^{-2} \mathrm{y}^{-1}$ (Moodley et al., 1998), we can estimate that from 25 to $78 \%$ of the organic carbon input to the sea bottom could be lost through benthic respiration at western coastal site under riverine influence (S1, S2, CS). If we take the respired carbon benthic fluxes estimated by Giordani et al. (2002) for the western NAd (100-130 $\left.\mathrm{gC} \mathrm{m}^{-2} \mathrm{y}^{-1}\right)$ the incidence of the utilization of the total organic carbon particle flux rises up to $47-114 \%$. Notwithstanding the variation of these estimates, these results suggests that a quite relevant fraction of the settling OC which is not buried in the sediments is likely consumed or remineralized at the sediment-water interface. At the sites S1, S2 and CS, highly influenced by rivers, a significant fraction of OC accumulated in the sediments results from the riverine discharge or from lateral advection. Therefore, we confirm that riverine or laterally advected labile organic matter must play a relevant role in sustaining the benthic trophic chain (Danovaro et al., 2000). The particulate organic matter carried by the Po River, especially during low discharge periods, is rich in phytoplankton (Pettine et al., 1998) which presumably is a source of allochthonous labile organic matter. As a matter of fact, both bacteria and meiofauna were shown to respond to frontal areas created by plumes and their associated gradients of settled organic matter particles south of the Po prodelta (Danovaro et al., 2000).

\section{CONCLUSIONS}

The downward fluxes of particles in the NAd present strong gradients decreasing from west to east. The coastal areas influenced by higher riverine inputs (Po and Adige Rivers) are characterised by higher productivity but lower carbon export when expressed as percentage of primary production. In offshore waters, primary production is lower but the organic carbon transfer to the bottom in percentage is about double with respect to the coastal areas. Downward fluxes and the elemental composition of settling matter are characterised by high seasonal variations. The sink of particles occurs in relatively short episodes as about $50 \%$ of annual flux occurs in less than 2-3 months.

In the shallow continental shelf of the northern Adriatic, resuspension and advective transport, accounting for up to $70-90 \%$ of the total organic carbon flux at annual scale, are the main processes regulating the dynamic of particles, their concentration and sedimentation. The importance of these processes is highlighted by the relevance of carbonates, which represent a substantial component of the fluxes in the north-western area of the NAd and are associated with the river inputs and with the dispersion of sediments through resuspension.

At most sites, the autochthonous organic carbon fluxes were higher than the organic carbon accumulation at the surficial sediment as estimated by radionuclide data, and this excess likely contributes to sustain the biological and chemical processes in the sediment.

In the areas influenced by higher riverine discharges, the total sedimentation of OC, estimated at annual scale, is much higher than the flux due to the primary production, then a relevant allochthonous source of organic matter is required to sustain the benthic community.

Future studies with sediment traps in the area should include a more detailed characterization of the lithogenic fraction and should also trace the organic matter sources with stable isotopes in order to better estimate the contributions of resuspension processes, and of riverine versus marine matter.

\section{ACKNOWLEDGMENTS}

Part of this work was financially supported by VECTOR-FISR project of the Italian Ministry for University and Research. The data of sites S1, S2 and S3 were produced in the framework of PRISMA-1 "Programma di Ricerca e sperimentazione per la Salvaguardia del Mare Adriatico" project, financially supported by the Italian Ministry for University and Research. The data for the site MI were produced in the framework of PRISMA-1 and MAT "Programma di monitoraggio e studio sui processi di formazione delle Mucillagini nell'Adriatico e nel Tirreno" project, financially supported by the Italian Ministry for the Environment and the Safeguard of the Territory and the Sea. The data for the site CS were produced in the framework of "Intervento 72 - Campo Sperimentale in 
Mare" project, financially supported by the Veneto Region and coordinated by ARPAV- Regional Agency for Prevention, Environment and Energy of Veneto (Italy).

We thank all the technicians and researchers of CNR, of ICRAM and of the other institutions who collaborated to the field and laboratory work and contributed to produce the data that were used in the present work.

\section{REFERENCES}

Ambrose RF, Anderson TW, 1990. Influence of an artificial reef on the surrounding infaunal community. Mar. Biol. 107: 41-52.

ARPAV, 2018. [Stime delle portate alla foce dei principali corsi d'acqua del Veneto per il triennio 2014-16, ai fini della valutazione dei carichi veicolati in Adriatico].[Report in Italian]. Nota Tecnica n. 06/18: 39 pp.

Autorità di bacino dell'Adige e dei fiumi dell'Alto Adriatico, 2009. [Documento di Piano, Pressioni - Bacino del fiume Sile, pp. 1-25].[Report in Italian]. Autorità di bacino dell'Adige e dei fiumi dell'Alto Adriatico, Venezia.

Autorità di bacino dell'Adige e dei fiumi dell'Alto Adriatico, 2009. [Documento di Piano, Pressioni - Bacino del fiume Piave, pp. 1-66].[Report in Italian]. Autorità di bacino dell'Adige e dei fiumi dell'Alto Adriatico, Venezia.

Bernardi F, Berton A, Bastianini M, Socal G, Acri F, 2004. Phytoplankton succession in a coastal area of the NW Adriatic over a 10-years sampling period (1990-1999). Cont. Shelf Res. 24:97-115.

Berger WH, Wefer G, 1990. Export production: seasonality and intermittency, and paleoceanographic implication. Palaeogeogr. Palaeoclimatol. Palaeoecol. 89:245-254.

Bertuzzi A, Faganeli J, Welker C, Brambati A, 1997. Benthic fluxes of dissolved inorganic carbon, nutrients and oxygen in the Gulf of Trieste (Northern Adriatic). Water Air Soil Poll. 99:305-314.

Boldrin A, Miserocchi S, Rabitti S, Turchetto M, Balboni V, Socal G, 2002. Particulate matter in the Southern Adriatic and Ionian Sea: characterization and downward fluxes. J. Marine Syst. 33-34:389-410.

Boldrin A, Carniel S, Giani M, Marini M, Bernardi Aubry F, Campanelli A, Grilli F, Russo A, 2009. Effects of bora wind on physical and biogeochemical properties of stratified waters in the northern Adriatic. J. Geophys. Res. 114: C08S92. doi: 10.1029/2008JC004837.

Boldrin A, Langone L, Miserocchi S, Turchetto M, Acri F, 2005. Po river plume on the Adriatic continental shelf: observations on dispersion and sedimentation dynamics of dissolved and suspended matter during different river discharge rates. Mar. Geol. 222-223:135-158.

Boldrin A, De Lazzari A, Pugnetti A, Bazzoni AM, Cassin D, Turchetto $\mathrm{M}, 2006$. [Produttività primaria, flussi verticali di materiale particellato ed export di carbonio organico nell'area del Campo Sperimentale, p. 70-82]. In: [Campo Sperimentale in mare: prime esperienze nel Veneto relative a elevazioni del fondale con materiale inerte].[Book in Italian]. ARPAV-Regione del Veneto.

Bogunović B, Malačič V, 2009. Circulation in the Gulf of
Trieste: Measurements and model results. Il Nuovo Cimento 31:301-326.

Brambati A, Ciabatti M, Fanzutti GP, Marabini F, Marocco R, 1983. A new sedimentological textural map of the northern and central Adriatic Sea. Boll. Oceanogr. Teor. App. I 267-271.

Brambati A, Bregant D, Lenardon G, Stolfa D, 1973. Transport and sedimentation in the Adriatic Sea. Museo friulano di Storia Naturale, Pubbl. n. 20, Udine: 60 pp.

Brando VE, Braga F, Zaggia L, Giardino C, Bresciani M, Matta E, Bellafiore D, Ferrarin C, Maicu F, Benetazzo A, Bonaldo D, Falcieri FM, Coluccelli A, Russo A, Carniel S, 2015. High-resolution satellite turbidity and sea surface temperature observations of river plume interactions during a significant flood event. Ocean Sci. 11:909-920.

Brondi A, Ferretti O, Anselmi B, Falchi G, 1979. [Analisi granulometriche e mineralogiche dei sedimenti fluviali e costieri del territorio italiano].[Article in Italian]. Boll. Soc. Geol. Ital. 98:293-326.

Buesseler KO, Antia AN, Chen M, Fowler SW, Gardner WD, Gustafsson O, Harada K, Michaels AF, Rutgers van der Loeff M, Sarin M, Steinberg DK, Trull TW, 2007. An assessment of the use of sediment traps for estimating upper ocean particle fluxes. J. Mar. Res. 65:345-416.

Colella S, Falcini F, Rinaldi E, Sammartino M, Santoleri R, 2016. Mediterranean Ocean colour chlorophyll trends. PLoS One 11:e0155756. doi:10.1371/journal.pone.0155756.

Correggiari A, Trincardi F, Langone L, Roveri M, 2001. Styles of failure in late Holocene highstand prodelta wedges on the Adriatic shelf. J. Sediment. Res. Part B 71:218-236.

Cozzi S, Falconi CF, Comici C, Čermelj B, Kovac N, Turk V, Giani M, 2012. Recent evolution of river discharges in the Gulf of Trieste and their potential responses to anthropogenic pressure and climate change. Estuar. Coast. Shelf Sci. 115:14-24.

Cozzi S, Giani M, 2011. River water and nutrient discharges in the Northern Adriatic Sea: current importance and long-term changes. Cont. Shelf Res. 31:1881-1893.

Danovaro R, Gambi C, Manini E, Fabiano M, 2000. Meiofauna response to a dynamic river plume front. Mar. Biol. 137: 359-370.

De Lazzari A, Boldrin A, Cassin D, 2006. [Caratteristiche tessiturali e chimiche dei sedimenti superficiali nell'area a barriere artificiali del "Campo Sperimentale" p. 85-96]. In: [Campo Sperimentale in mare: prime esperienze nel Veneto relative a elevazioni del fondale con materiale inerte].[Book in Italian]. ARPAV-Regione del Veneto.

D'Ortenzio F, Ribera d'Alcala M, 2009. On the trophic regimes of the Mediterranean Sea: a satellite analysis. Biogeosciences 6:139-148.

Falcão M, Santos MN, Drago T, Serpa D, Monteiro C, 2009. Effect of artificial reefs (southern Portugal) on sedimentwater transport of nutrients: Importance of the hydrodynamic regime. Estuar. Coast. Shelf Sci. 83:451-459.

Faganeli J, 1989. Sedimentation of particulate Nitrogen and Amino acids in shallow coastal waters (gulf of Trieste, northern Adriatic). Mar. Chem. 26:67-80.

Faganeli J, Malej A, Pezdic J, Malacic V, 1988. C: N: P ratios and stable $\mathrm{C}$ isotopic ratios as indicators of sources of organic matter in the gulf of Trieste (northern Adriatic). Oceanol. Acta 11:377-382. 
Faganeli J, Planinc R, Pezdic J, Smodis B, Stegnar P, Ogorelec B, 1991. Marine geology of the gulf of Trieste (northern Adriatic): geochemical aspects. Mar. Geol. 99:93-108.

Fain AMV, Ogston AS, Sternberg RW, 2007. Sediment transport event analysis on the western Adriatic continental shelf. Cont. Shelf Res. 27:431-451.

Fonda Umani S, Del Negro P, Larato C, De Vittor C, Cabrini M, Celio M, Falconi C, Tamberlich F, Azam F, 2007. Major inter-annual variations in microbial dynamics in the Gulf of Trieste (northern Adriatic Sea) and their ecosystem implications. Aquat. Microb. Ecol. 46:163-175.

Fox JM, Hill PS, Milligan TG, Ogston AS, Boldrin A, 2004. Floc fraction in the waters of the Po River prodelta. Cont. Shelf Res. 24:1699-1715.

Franco P, Jeftic L, Malanotte Rizzoli P, Michelato A, Orlic M, 1982. Descriptive model of the Northern Adriatic. Oceanol. Acta 5: 379-389.

Frignani M, Langone L, Ravaioli M, Sorgente D, Alvisi F, Albertazzi S, 2005. Fine-sediment mass balance in the western Adriatic continental shelf over a century time scale. Mar. Geol. 222-223:13-133.

Gasith A, 1975. Tripton sedimentation in eutrophic lake-simple correction for suspended matter. Verhand.nIntern. Verein. Limnol. 19:116-122.

Giani M, Alberighi L, Bacci C, Boldrin A, Puddu A, Rabitti S, 1999. A preliminary approach to the carbon cycling in the Northern Adriatic Sea, p. 251-267. In: T.S. Hopkins, A. Artegiani, G. Cauwet, D. Degobbis and A. Malej (eds.), Ecosystem research report n. 32: the Adriatic Sea. European Commission, Brussel.

Giani M, Berto D, Rampazzo F, Savelli F, Alvisi F, Giordano P, Ravaioli M, Frascari F, 2009. Origin of sedimentary organic matter in the north-western Adriatic Sea. Estuar. Coast. Shelf Sci. 84:573-583.

Giani M, Boldrin A, Matteucci G, Frascari F, Gismondi M, Rabitti S, 2001. Downward fluxes of particulate carbon, nitrogen and phosphorus in the North Western Adriatic Sea. Sci. Tot. Environ. 266:125-134.

Giani M, Bortolozzo F, Gismondi M, Manzueto L, Righi S, Romano E, Savelli F, Trentin A, 1997. [Carbonio azoto e fosforo nei sedimenti dell'Adriatico: distribuzione e variazioni dei rapporti $\mathrm{C}: \mathrm{N}: \mathrm{P}$ nei processi sedimentari recenti]. Rapporto finale. Programma di Ricerca e sperimentazione per la Salvaguardia del Mare Adriatico (PRISMA), Sotto-progetto "Valutazione dei carichi esogeni - Valutazione dei flussi da e verso i fondali", ICRAM, Chioggia, pp. 1-80. [In italian].

Giani M, Djakovac T, Degobbis D, Cozzi S, Solidoro C, Fonda Umani S, 2012. Recent changes in the marine ecosystems of the northern Adriatic Sea. Estuar. Coast. Shelf Sci. 115:1-13.

Giani M, Rampazzo F, Berto D, 2010. Humic acids contribution to sedimentary organic matter on a shallow continental shelf (northern Adriatic Sea). Estuar. Coast. Shelf Sci. 90:103-110.

Giani M, Savelli F, Berto D, Zangrando V, Ćosović B, Vojvodić $\mathrm{V}, 2005$. Temporal dynamic of dissolved and particulate organic carbon in the northern Adriatic Sea in relation to the mucilage events. Sci. Tot. Environ. 353:126-138.

Giani M, Savelli F, Boldrin A, 2003a. Temporal variability of particulate organic carbon, nitrogen and phosphorus in the northern Adriatic Sea. Hydrobiologia 494: 319-325.
Giani M, Savelli F, Ciriaco S, Odorico R, 2003b. [Flussi verticali di particellato sedimentabile nel golfo di Trieste], p. 367386. In: [Programma di monitoraggio e studio sui processi di formazione delle Mucillagini nell'Adriatico e nel Tirreno. Rapporto finale].[Report in Italian]. MAT, ICRAM, Roma.

Gilmartin M, Revelante N, 1983. The phytoplankton of the Adriatic Sea: standing crop and primary production. Thalassia jugoslavica 19:173-188.

Giordani P, Helder W, Koning E, Miserocchi S, Danovaro R, Malaguti A, 2002. Gradients of benthic-pelagic coupling and carbon budgets in the Adriatic and Northern Ionian Sea. J. Marine Syst. 33-4: 365-387.

Godrijan J, Young JR, Marić Pfannkuchen D, Precali R, Pfannkuchen M, 2018. Coastal zones as important habitats of coccolithophores: A study of species diversity, succession, and life-cycle phases. Limnol. Oceanogr. 63:1692-1710.

Goñi MA, Hedges JI, 1995. Sources and reactivities of marine derived organic matter in coastal sediments as determined by alkaline $\mathrm{CuO}$ oxidation. Geochim. Cosmochim. Acta 59:2965-2981.

Goñi MA, Thomas KA, 2000. Sources and transformations of organic matter in surface soils and sediments from a tidal estuary, North Inlet, South Carolina, USA. Estuaries 23: 548-564.

Hedges J, Stern JH, 1984. Carbon and nitrogen determinations of carbonate-containing solids. Limnol. Oceanogr. 29:657-663.

Heussner S, Ratti C, Carbonne J, 1990. The PPS3 time-series sediment trap and the trap sample processing techniques used during the ECOMARGE experiment. Cont. Shelf Res. 10:943-958.

Lampitt RS, Antia AN, 1997. Particle flux in deep seas: regional characteristics and temporal variability. Deep-Sea Res. Pt. I 44:1377-1403.

Lazzari P, Solidoro C, Ibello V, Salon S, Teruzzi A, Beranger K, Colella S, Crise A, 2012. Seasonal and inter-annual variability of plankton chlorophyll and primary production in the Mediterranean Sea: a modelling approach. Biogeosciences 9:217-233.

Lipizer M, Partescano E, Rabitti A, Giorgetti A, Crise A, 2014. Qualified temperature, salinity and dissolved oxygen climatologies in a changing Adriatic Sea. Ocean Sci. 10: 771-797.

Langone L, Miserocchi S, Boldrin A, Bonaldo D, Carniel S, Chiggiato J, Turchetto M, Borghini M, Tesi T, 2016. Dynamics of particles along the western margin of the Southern Adriatic: Processes involved in transferring particulate matter to the deep basin. Mar. Geol. 375: 28-43.

Luchetta A, Cantoni C, Catalano G, 2010. New observations of $\mathrm{CO}_{2}$-induced acidification in the northern Adriatic Sea over the last quarter century. Chem. Ecol. 26:1-17.

Ludwig W, Dumont E, Meybeck M, Heussner S, 2009. River discharges of water and nutrients to the Mediterranean and Black Sea: Major drivers for ecosystem changes during past and future decades? Prog. Oceanogr. 80:199-217.

Malačič V, Petelin B, 2009. Climatic circulation in the Gulf of Trieste (northern Adriatic). J. Geophys. Res. 114:C07002. doi: 10.1029/2008JC004904.

Marty JC, Goutx M, Guigue C, Leblond N, Raimbault P, 2009. Short-term changes in particulate fluxes measured by drifting sediment traps during end summer oligotrophic 
regime in the NW Mediterranean Sea. Biogeosciences 6:887-899.

Matteucci G, Frascari F, 1997. Fluxes of suspended materials in the north Adriatic sea (Po prodelta area). Water Air Soil Poll. 99:557-572

Mauri E, Poulain P-M, Juznic-Zonta Z, 2007. MODIS chlorophyll variability in the northern Adriatic Sea and relationship with forcing parameters. J. Geophys. Res. 112:C03S11. doi:10.1029/2006JC003545.

Miquel JC, Fowler S, Hamilton T, Heilrnann J, La Rosa J, Carrol M, 1999. Carbon fluxes and export in the northern and central Adriatic Sea measured with drifting sediment traps, p. 509-524. In: T.S. Hopkins, A. Artegiani, G. Cauwet, D. Degobbis and A. Malej (eds.), Ecosystem research report n. 32: the Adriatic Sea. European Commission, Brussel.

Miquel JC, Fowler SW, La Rosa J, Buat-Menard P, 1994. Dynamics of the downward flux of particles and carbon in the open northwestern Mediterranean Sea. Deep-Sea Res. Pt. I 41:243-261.

Miquel J-C, Martín J, Gasser B, Rodriguez-y-Baena A, Toubal T, Fowler SW, 2011. Dynamics of particle flux and carbon export in the northwestern Mediterranean Sea: a two decade time-series study at the DYFAMED site. Prog. Oceanogr. 91:461-481.

Moodley L, Heip CHR, Middelburg JJ, 1998. Benthic activity in sediments of the northwestern Adriatic Sea: sediment oxygen consumption, macro- and meiofauna dynamics. J. Sea Res. 40:263-280.

Mozetič P, Solidoro C, Cossarini G, Socal G, Precali R, Francé J, Bianchi F, De Vittor C, Smodlaka N, Umani SF, 2010. Recent trends towards oligotrophication of the northern Adriatic: Evidence from chlorophyll a time series. Estuar. Coast. 33:362-375.

Ogorelec B, Mišič M, Faganeli J, 1991. Marine geology of the Gulf of Trieste (northern Adriatic): sedimentological aspects. Mar. Geol. 99:79-92.

Ogrinc N, Faganeli J, Pezdic J, 2003. Determination of organic carbon remineralization in near-shore marine sediments (Gulf of Trieste, Northern Adriatic) using stable carbon isotopes. Org. Geochem. 34:681-692.

Perdue EM, Koprivnjak JF, 2007. Using the $\mathrm{C} / \mathrm{N}$ ratio to estimate terrigenous inputs of organic matter to aquatic environments. Estuar. Coast. Shelf Sci. 73:65-72.

Pettine M, Patrolecco L, Camusso M, Crescenzio S, 1998. Transport of carbon and nitrogen to the northern Adriatic sea by the Po river. Estuar. Coast. Shelf Sci. 46:127-142.

Puddu A, La Ferla R, Allegra A, Bacci C, Lopez M, Oliva F, Pierotti C, 1998. Seasonal and spatial distribution of bacterial production and biomass along a salinity gradient (Northern Adriatic Sea). Hydrobiologia 363:271-282.

Pugnetti A, Camatti E, Mangoni O, Morabito G, Oggioni A, Saggiomo A, 2006. Phytoplankton production in Italian freshwater and marine ecosystems: State of the art and perspectives. Chem. Ecol. 22:S49-S69.

Puškaric S, Fowler SW, Miquel JC, 1992. Temporal changes in particulate flux in the northern Adriatic sea. Estuar. Coast. Shelf Sci. 35:267-287.

Ramondenc S, Goutx M, Lombard F, Santinelli C, Stemmann L, Gorsky G, Guidi L, 2016. An initial carbon export assessment in the Mediterranean Sea based on drifting sediment traps and the Underwater Vision Profiler data sets. Deep-Sea Res. Pt. I 117:107-119.

Ravaioli M, Alvisi F, Menegazzo Vitturi L, 2003. Dolomite as a tracer for sediment transport and deposition on the northwestern Adriatic continental shelf (Adriatic Sea, Italy)., Cont. Shelf Res. 23:1359-1377.

Rizzo G, Boldrin A, De Lazzari A, Bressan M, 2009. Swimmers in trappole per il sedimento nel Nord Adriatico - Swimmers in sediment traps in the Northern Adriatic Sea. Biol. Mar. Mediterr. 16:154-157.

Smodlaka N, 1986. Primary production of the organic matter as an indicator of the eutrophication in the northern Adriatic Sea. Sci. Total Environ. 56:211-220.

Solidoro C, Bastianini M, Bandelj V, Codermatz R, Cossarini G, Melaku Canu D, Ravagnan E, Salon S, Trevisani S, 2009. Current state, scales of variability, and trends of biogeochemical properties in the northern Adriatic Sea. J. Geophys. Res. 114:C07S91. doi: 10.1029/2008JC004838.

Stavrakakis S, Chronis G, Tselepides A, Heussner S, Monaco A, Abassi A, 2000. Downward fluxes of settling particles in the deep Cretan Sea (NE Mediterranean). Prog. Oceanogr. 46: 217-240.

Tesi T, Langone L, Ravaioli M, Giglio F, Capotondi L, 2012. Particulate export and lateral advection in the Antarctic Polar Front (Southern Pacific Ocean): One-year mooring deployment. J. Marine Syst. 105-108:70-81.

Tesi T, Miserocchi S, Goñi MA, Langone L, Boldrin A, Turchetto M, 2007. Organic matter origin and distribution in suspended particulate materials and surficial sediments, from the western Adriatic Sea (Italy). Estuar. Coast. Shelf Sci. 73:431-446.

Turchetto M, Boldrin A, Rabitti S, Acri F, Comaschi A, 2002. Particulate matter and downward flux in the northern and central Adriatic Sea. Chem. Ecol. 18:127-141.

USGOFS (Global Ocean Flux Study), 1989. Sediment trap technology and sampling. Report of the U.S. GOFS Working Group on Sediment Trap Technology and Sampling. WHOI: $94 \mathrm{pp}$.

Viličić D, Djakovac T, Burić Z, Bosak S, 2009. Composition and annual cycle of phytoplankton assemblages in the northeastern Adriatic Sea. Bot. Mar. 52:291-305.

Wang XH, Pinardi N, 2002. Modeling the dynamics of sediment transport and resuspension in the northern Adriatic Sea. J. Geophys. Res. 107:3225. doi: 10.1029/2001JC001303.

Wang XH, Pinardi N, Malicic V, 2007. Sediment transport and resuspension due to combined motion of waves and currents in the northern Adriatic Sea during a Bora event in January 2001: A numerical modelling study. Cont. Shelf Res. 27:613-633.

Wassman P, Fonda Umani S, Ypma JE, Reigstad M, Cok S, Salvi C, Cauwet G, 1999. Suspended biomass and vertical flux in the gulf of Trieste (Northern Adriatic Sea): two summer scenarios, p. 537-55. In: T.S. Hopkins, A. Artegiani, G. Cauwet, D. Degobbis and A. Malej (eds.), Ecosystem research report n. 32: the Adriatic Sea. European Commission, Brussel.

Zennaro E, Scatto D, Patti S, 2006. [Prima realizzazione in Veneto di elevazioni del fondale con materiale inerte: il "campo sperimentale in mare"], p. 35-45. [Campo Sperimentale in mare: prime esperienze nel Veneto relative a elevazioni del fondale con materiale inerte].[Book in Italian]. ARPAVRegione del Veneto. 